\title{
Progress in Myocardial Regeneration and Cell Transplantation
}

\author{
Keiichi Fukuda, MD
}

\begin{abstract}
Embryonic stem cells and bone marrow mesenchymal stem cells can be induced to differentiate into cardiomyocytes. Techniques to purify and transplant regenerated cardiomyocytes have been developed, and transplanted regenerated cardiomyocytes are capable of residing in the heart of recipients for long periods. Advances in tissue engineering technology have enabled the production of cardiomyocyte cell sheets for transplantation treatment of heart failure, without the need for a donor, and this has now reached the preclinical stage. The treatment of heart failure using cytokines to mobilize stem cells has also been explored. (Circ J 2005; 69: 1431-1446)
\end{abstract}

Key Words: Bone marrow mesenchymal stem cells; Cardiomyocytes; Cell transplantation; Embryonic stem cells; Heart failure; Regenerative medicine

C ardiomyocytes cease cell division immediately after birth and are thought to subsequently adapt to the demands placed on the heart by undergoing hypertrophy without cell division. Recent research has revealed that although a small number of cardiomyocytes do undergo cell division immediately after a myocardial infarction their contribution is not sufficient to improve heart failure, ${ }^{1,2}$ Heart transplantation is traditionally performed to treat intractable severe heart failure secondary to dilated and hypertrophic cardiomyopathy, but its use is restricted by a shortage of donors. The use of pluripotent stem cells to regenerate damaged heart tissue is being advocated as the new treatment for heart failure secondary to heart disease or severe myocardial infarction. Promising results at the research stage now provide the challenge of clinically applying stem cell technology. This paper reviews the recent progress in myocardial regeneration and cell transplantation in the author's laboratory.

\section{Cardiomyocyte Regeneration and Stem Cells}

Although stem cells are referred to as pluripotent, they are present at many different developmental stages, from those with the potential of becoming any organ in the body, such as embryonic stem (ES) cells, to those such as hematopoietic stem cells that are only capable of differentiating into specific cell types. In 1999 my group reported that bone marrow mesenchymal stem cells differentiate into cardiomyocytes ${ }^{3,4}$ It is now known that a variety of stem cells present in the body have the ability to differentiate into cardiomyocytes (Table 1$)^{3-8}$

\section{ES Cells as a Source of Cardiomyocytes}

The differentiation of ES cells into any lineage is at least partly dependent on the regulatory mechanisms of normal

(Received September 16, 2005; accepted September 16, 2005)

Department of Regenerative Medicine and Advanced Cardiac Therapeutics, Keio University School of Medicine, Tokyo, Japan

Mailing address: Keiichi Fukuda, MD, PhD, FACC, Professor and Chair, Department of Regenerative Medicine and Advanced Cardiac Therapeutics, Keio University School of Medicine, 35 Shinanomachi, Shinjuku-ku, Tokyo 160-8582, Japan. E-mail: kfukuda@sc.itc.keio. ac.jp early development. Although ES cells are an attractive source for the generation of cardiomyocytes, a lack of reliable selective differentiation methods has impeded the clinical application of ES cell technology for cardiomyocyte production. The potential of ES cells to form cardiomyocytes was realized when embryoid bodies (EB), a pseudoembryo with a central cavity formed by culturing ES cells in a suspended state, were shown to produce cardiomyocytes without specific induction of differentiation. It has subsequently been reported that cardiomyocytes can be specifically induced to differentiate from human ES cells! ${ }^{10}$ Although various factors are known to induce the differentiation of cardiomyocytes from EB, including bone morphogentic protein (BMP)-2,1 fibroblast growth factor (FGF) ${ }^{12}$ insulin-like growth factor (IGF)-1, ${ }^{13} \mathrm{H}_{2} \mathrm{O}_{2},{ }^{14}$ ascorbic acid, ${ }^{15}$ and retinoic acid 16 the level of cardiomyocyte production is not sufficient.

Several signals, including BMP ${ }^{19,20} \mathrm{Wnt}^{21}$ and $\mathrm{FGF}^{22}$ are involved in heart development, but there is little evidence available on the signals that mediate cardiomyocyte differentiation from ES cells, although it is known that the process may involve Wnt and Notch-mediated signals ${ }^{17,18}$ To investigate the signals underlying cardiomyocyte differentiation my group have developed an effective protocol for differentiating cardiomyocytes from ES cells. Although BMP signaling plays a crucial role in mesodermal induction and cardiac development, ${ }^{19,20}$ treatment of ES cells with BMP-2 or BMP-4 does not augment or suppress cardiomyocyte induction. In the vertebrate nervous system, Noggin and other BMP-inhibitors (Chordin and Follistatin) are involved in neural differentiation in a context-dependent fashion? 23,24 It is possible that BMP antagonists are also involved in cardiomyocyte induction. Whole-mount in situ hybridization with probes for various BMP antagonists on mouse embryos at different stages of gastrulation has been performed and the BMP antagonist, Noggin, was transiently but strongly expressed in the heart-forming area (Fig 1$)^{25}$ It was clearly expressed at the cardiac crescent at E7.5 and the late crescent stage at E8.0, but was barely detectable in the linear heart tube after E8.5. By comparison, notochord expression of Noggin continued after E8.5, as reported previously?6,27 E7.5 and E8.0 whole-mount sections revealed expression of Noggin in the endodermal and mesodermal 
Table 1 Classification and Characteristics of Myocardial Stem Cells

\begin{tabular}{|c|c|c|c|c|}
\hline & Authors & Characteristics & $\begin{array}{l}\text { Frequency of occurrencel } \\
\text { difficulty of isolation }\end{array}$ & Diffenrentiation capacity \\
\hline ES cells & Numerous & $\begin{array}{l}\text { Capable of mass culture. } \\
\text { Immunosuppressive agents } \\
\text { required for allogeneic } \\
\text { transplantation. }\end{array}$ & $\begin{array}{l}\text { Isolation relatively easy. } \\
\text { Human ES cells have } \\
\text { already been established. }\end{array}$ & $\begin{array}{l}\text { Can differentiate into wide variety } \\
\text { cells, but cells capable of } \\
\text { differentiating in the early embryonic } \\
\text { period are to obtain in vitro. }\end{array}$ \\
\hline $\begin{array}{l}\text { Bone marrow } \\
\text { mesenchymal } \\
\text { stem cells }\end{array}$ & $\begin{array}{l}\text { Fukuda et al, } \\
\text { Keio Univ. }\end{array}$ & $\begin{array}{l}\text { Culture method relatively } \\
\text { easy. }\end{array}$ & $\begin{array}{l}\text { One in several million to } \\
\text { several tens of millions } \\
\text { in bone marrow. }\end{array}$ & $\begin{array}{l}\text { Osteoblasts, chondroblasts, } \\
\text { adipocytes, cardiomyocytes, etc. }\end{array}$ \\
\hline MAPC cells & $\begin{array}{l}\text { Verfeille et al, } \\
\text { University } \\
\text { of Minnesota }\end{array}$ & $\begin{array}{l}\text { Culture method extremely } \\
\text { difficult. } \\
\text { Mass culture impossible. }\end{array}$ & $\begin{array}{l}\text { One in billion (extremely rare). } \\
\text { Isolation is difficult, but has } \\
\text { been done from human cells. }\end{array}$ & $\begin{array}{l}\text { Can differentiate into wide variety cells } \\
\text { including neurons, hepatocytes, } \\
\text { skeletal muscle cells. }\end{array}$ \\
\hline $\begin{array}{l}\text { Myocardial tissue } \\
\text { stem cells } \\
\text { (c-Kit cells) }\end{array}$ & $\begin{array}{l}\text { Anversa et al, } \\
\text { State University } \\
\text { of New York }\end{array}$ & $\begin{array}{l}\text { Isolation difficult. } \\
\text { Mass culture impossible. }\end{array}$ & $\begin{array}{l}\text { Difficult to use as material } \\
\text { for heart tissue. Unknown } \\
\text { whether possible by biopsy. }\end{array}$ & $\begin{array}{l}\text { Myocardium, smooth muscle, vascular } \\
\text { endothelial cells. }\end{array}$ \\
\hline $\begin{array}{l}\text { Myocardial tissue } \\
\text { stem cells } \\
\text { (Sca-1 cells) }\end{array}$ & $\begin{array}{l}\text { Schneider et al, } \\
\text { Baylor University }\end{array}$ & $\begin{array}{l}\text { Isolation difficult. } \\
\text { Mass culture impossible. }\end{array}$ & $\begin{array}{l}\text { Impossible-humans do not } \\
\text { possess the Sca-1 antigen. }\end{array}$ & Myocardium \\
\hline
\end{tabular}

ES, embryonic stem; MAPC, multipotent adult progenitor cell.

layers derived from the primary heart field. This marked difference in the time course of Noggin expression between the heart-forming region and notochord suggests that transient expression of Noggin has a function in cardiomyocyte differentiation.

Murine ES cells in suspension culture were stimulated with Noggin under various experimental conditions (Fig 2).25 ES cell cultures were exposed to Noggin before or after EB formation to model the transient and strong expression of Noggin at the early gastrulation stage. Removal of leukocyte inhibitory factor (LIF) and the addition of Noggin before or after EB formation did not increase the incidence of spontaneously beating EB. By comparison, removal of LIF and addition of Noggin at days -3 and 0 from EB formation, slightly but significantly increased the incidence of beating EB, suggesting that the optimal timing for Noggin might be both prior to and after EB formation. Noggin was then added at days $-3,0,+1,+2$ or +3 , and LIF prior to EB formation. Adding Noggin at day 0 slightly increased the incidence of beating EB, but gradually decreased it at the other time points. Based on these results, Noggin was administered at days -3 and 0 from EB formation, and this led to a marked increase in the incidence of beating EB to $95.3 \%$ at 10 days, and continued growth of EB to day 14. Two independent ES cell lines behaved consistently and the optimal concentration of Noggin was $150 \mathrm{ng} / \mathrm{ml}$. These results suggest that the induction of cardiomyocytes by Noggin is restricted to the period from 3 days prior to 1 day after EB formation, and that the ES cells must initially be undifferentiated.

To demonstrate specific inhibition of the BMP pathway by Noggin the ES cells were exposed to various concentrations of BMP-2 at day 0 . The results confirmed that even low doses of BMP-2 strongly inhibited Noggin-dependent cardiomyocyte induction. To confirm whether inhibition of BMP signaling early in ES cell differentiation can accelerate cardiomyocyte induction, ES cells were also exposed to soluble BMP receptor-1A (BMPR-1A), or another BMP antagonist, Chordin. Both BMPR-1A and Chordin augmented the incidence of onset of beating in individual EBs. By comparison, administration of various growth factors, including IGF-1, FGF-2, and BMP-2, under the same condi- tions did not boost cardiomyocyte induction. These results suggest that inhibition of BMP signaling in undifferentiated ES cells or in the early phase of ES cell differentiation is crucial for cardiomyocyte differentiation.

Cardiomyocyte induction by Noggin was quantified by immunostaining for cardiac-specific proteins and the results were examined by confocal LASER microscopy. Most cells in the Noggin-treated EBs stained positive for myosin heavy chain (MHC), myosin light chain (MLC), atrial natriuretic peptide (ANP), cardiac troponin I, and sarcomeric actinin (Fig 3) ${ }^{25}$ In contrast, these cardiac proteins were markedly lower in the control or in EBs treated with Noggin under different conditions. Synchronous beating of EBs was observed and isolated cells expressed many cardiac markers and displayed myocyte characteristics. By day 10, EBs had attached to gelatin-coated dishes, stained with anti-MHC antibodies and contained a 100-fold increase in the number of cardiomyocytes.

Accumulating evidence implicates BMP signaling in cardiac differentiation. In chick embryos, exposure of explant cultures to BMP-2 or BMP-4 induces full cardiac differentiation in stage 5 to 7 anterior medial mesoderm, a tissue that is normally not cardiogenic 28,29 By comparison, both BMP-2 and BMP-4 inhibit cardiomyogenesis prior to stage 3 or during the early stages of gastrulation $3^{30}$ Although BMPs are expressed in lateral plate mesoderm, including the anterior lateral plate ${ }^{31}$ stimulation of ES cells by BMP-2 or BMP-4 does not augment cardiomyocyte differentiation. Together, these results suggest that BMPs play multiple roles in mesodermal induction and specific organ differentiation, and that their temporal and spatial expression is critical in cardiomyocyte induction 30

If the action of BMP in cardiomyocyte induction is analogous to its context-dependent differential action, the action of BMPs in cardiomyocyte induction may be explained by the local action of Noggin and other BMP inhibitors. Noggin is temporally but strongly expressed at the anterolateral plate in mouse embryos at E7.0-E8.0, and plays a critical role in cardiomyocyte induction. The restricted and highly effective window of Noggin's inductive action for cardiomyocyte differentiation from ES cells matches exactly the conditions during normal developmental of the heart in 
A
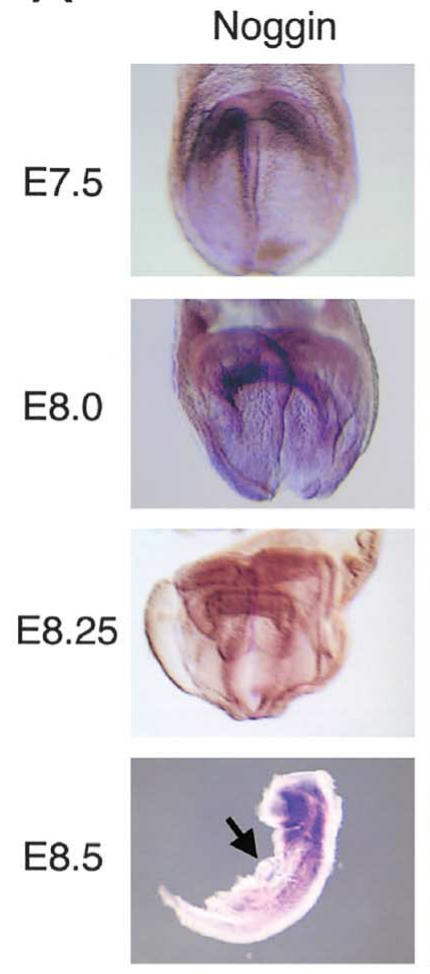

E9.0

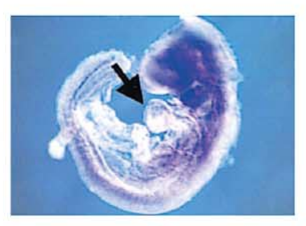

B

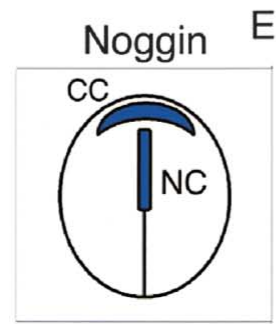

Nkx2.5
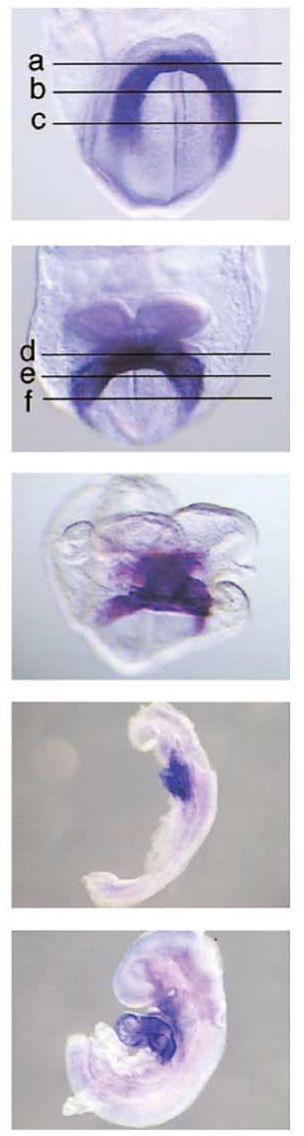

E7.5 Nkx2.5

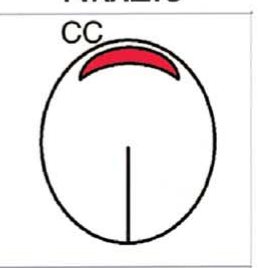

C

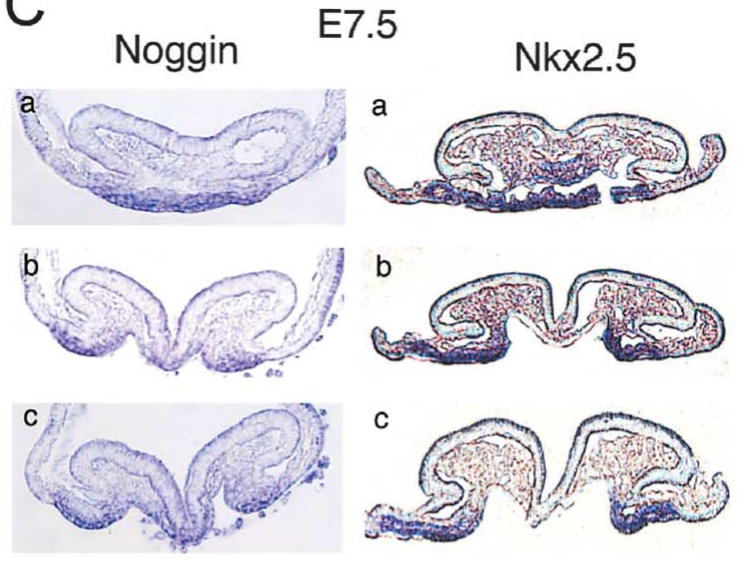

E8.0
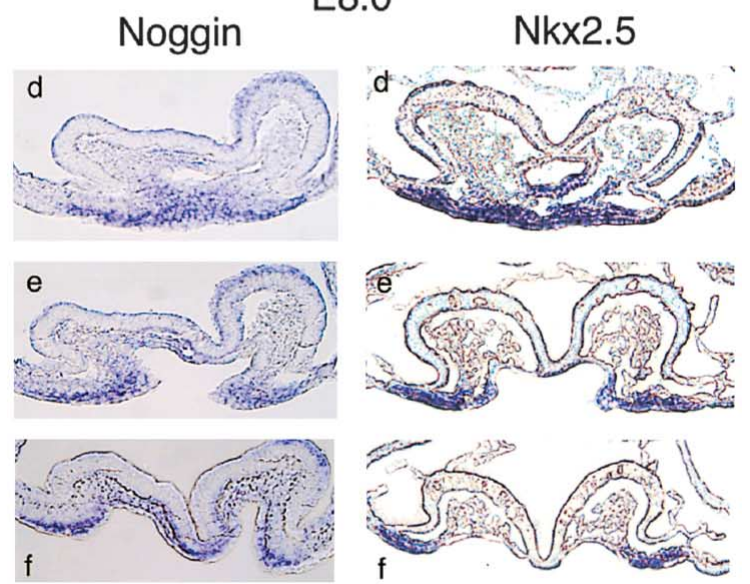

D

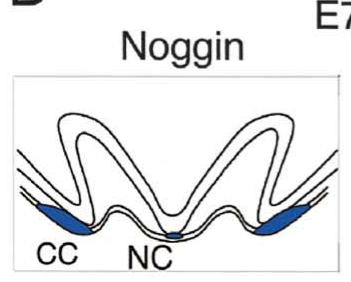

E7.5

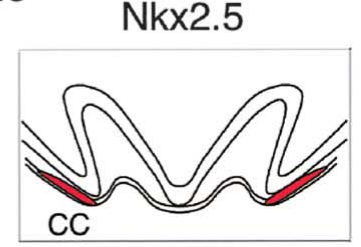

Fig 1. Transient expression of Noggin at the heart forming area. (A) Whole-mount in situ hybridization of Noggin and Nkx2.5 was performed at mouse embryo stages E7.5, E8.0, E8.5 and E9.0. Noggin was strongly expressed at the cardiac crescent (E7.5) and linear heart tube (E8.0), but was undetected after E8.5. By comparison, Nkx2.5 was expressed after this stage in development. Arrows indicate the heart. (B) The schema of Noggin and Nkx2.5 expression at E7.5. CC, cardiac crescent; NC, notochord; LHT, linear heart tube. (C) Section of samples at E7.5 and E8.0 with whole mount insitu hybridization. a-f represents the site of the section shown in (A). (D) Schema of Noggin and Nkx2.5 expression at E7.5 (Reprinted from Yuasa et al. Nat Biotech 2005; 23: 607-611).

E7.0-E8.0 embryos. Those results suggest that BMP signaling is essential for at least 2 steps in the cardiomyocyte induction process: mesodermal induction ${ }^{32}$ and cardiomyocyte differentiation. ${ }^{19,20}$ Between these steps, it is proposed that a transient block of intrinsic BMP signaling is essential for the determination of cardiomyogenic (CMG) differentiation.

The temporal and spatial expression of Noggin and BMP-2 is important for the in vivo and in vitro differentiation of cardiomyocytes, in addition to the central nervous system. The protocol used by my group is predicted to advance the use of ES cell-derived cardiomyocytes in regenerative therapy.

\section{Bone Marrow Mesenchymal Stem Cells as a Source} of Cardiomyocytes

Hematopoietic stem cells account for more than $99 \%$ of the bone marrow, whereas mesenchymal stem cells are present at low levels. Mesenchymal cells have the capacity to differentiate into osteoblasts, chondrocytes, and adipocytes ${ }^{33,34}$ and it has also been reported that they differentiate into skeletal muscle cells, cardiomyocytes,3,4 and neurons 35 The possibility that marrow stromal cells might also differentiate into cardiomyocytes lead to screening for marrow 
A

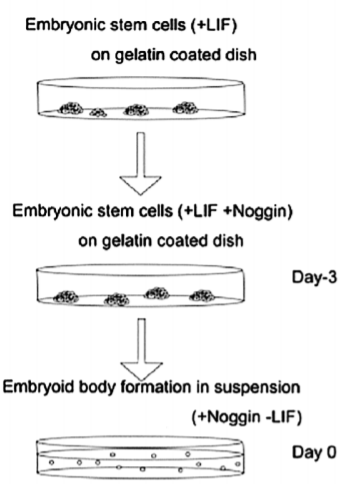

$\mathrm{D}$

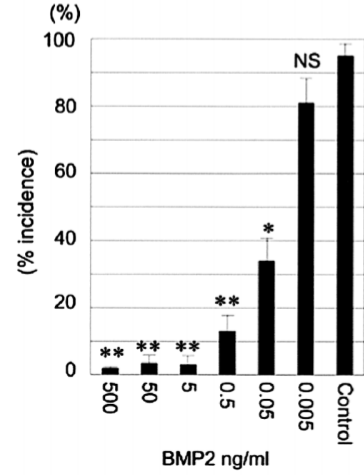

B

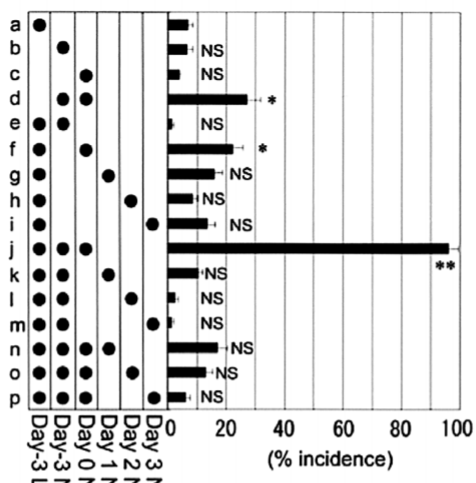

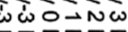

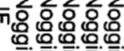

$\mathrm{E}$

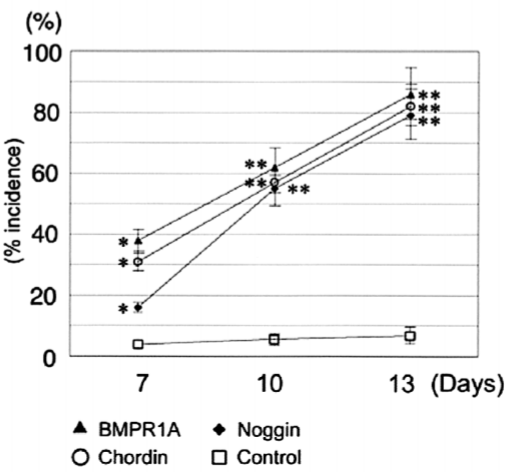

C

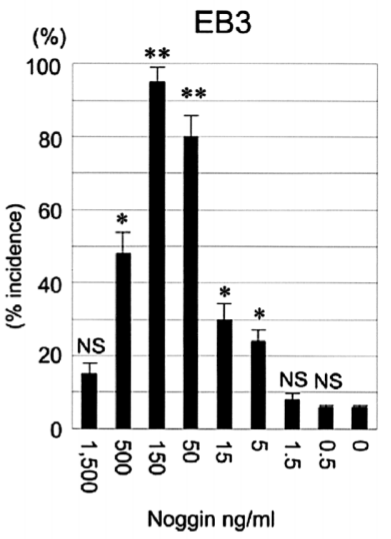

$\mathrm{F}$

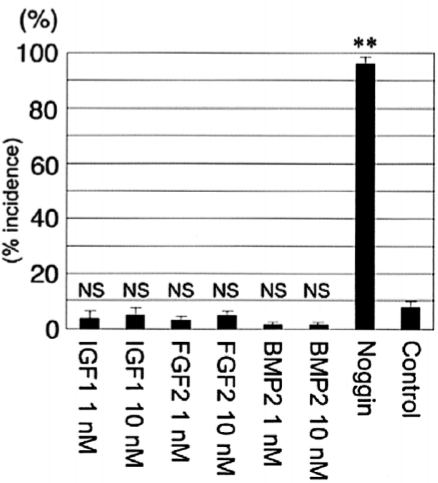

Fig 2. Protocol and efficiency of cardiomyocyte induction from embryonic stem (ES) cells using Noggin, Chordin and soluble bone morphogentic protein (BMP) recptor-1A. (A) Representative schema of the protocol of cardiomyocyte induction from ES cells. (B) Various protocols for Noggin $(150 \mathrm{ng} / \mathrm{ml})$ exposure were performed and their efficiency compared. (C) Dose-efficiency relationship of Noggin administration was demonstrated using 2 different ES cell lines, embryoid bodies 3 and R1 (supplemental Fig 1). Both cell lines show the same dose-efficiency relationship. (D) Administration of a low dose of BMP-2 abolished the effect of Noggin for cardiomyocyte induction, indicating that BMP-2 concentration was critical in this phenomenon. (E) Effect of other BMP antagonists, Chordin and soluble BMPR-1A (BMP neutralizing receptor), on cardiomyocyte induction. Both Chordin and BMPR-1A were administered using the same protocol as Noggin $(150 \mathrm{ng} / \mathrm{ml})$. Both of these BMP antagonists induced cardiomyocyte induction from ES cells at the same level as Noggin, indicating that transient relief from the intrinsic BMP signal is critical for cardiomyocyte induction. (F) Other factors including insulin-like growth factor-1, FGF-2 and BMP-2 did not affect cardiomyocyte induction with this protocol. ${ }^{*} \mathrm{p}<0.05,{ }^{*} \mathrm{p}<0.01$ vs control. NS, not significant (Reprinted from Yuasa et al. Nat Biotech 2005; 23: 607611).

stromal cells that began to spontaneously beat after exposure to 5-azacytidine, a cytosine analog capable of altering expression of certain genes that regulate differentiation. Adult marrow stromal cells were used to isolate a cell line, known as CMG that differentiates into cardiomyocytes. The use of adult tissue as the source of cardiomyocytes makes this system particularly suitable for the development of cardiomyocytes for transplantation. Clonal analysis led to the isolation of several clones that could differentiate into cardiomyocytes and show spontaneous beating. These experiments were reproducible, but the percentage of differentiated cardiomyocytes differed between the clones.

Phase-contrast microscopy revealed that CMG cells displayed a fibroblast-like morphology before 5-azacytidine treatment ( 0 week), a phenotype that was retained through repeated subculture under non-stimulating conditions. Within 1 week of 5-azacytidine treatment the morphology of the cells gradually changed, with approximately $30 \%$ of the cells gradually increasing in size to form a ball-like ap- pearance, or lengthening in 1 direction, forming a stick-like shape. Adjoining cells connected after 2 weeks and formed myotube-like structures after 3 weeks (Fig 4). The differentiated CMG myotubes did not de-differentiate and maintained the cardiomyocyte phenotype and beat vigorously for at least 8 weeks after the final 5-azacytidine treatment. Most of the other non-myocytes resembled adipocytes.

Transmission electron microscopy revealed that differentiated CMG myotubes had the typical striation and palestaining pattern of sarcomeres with nuclei positioned in the center of the cell, not beneath the sarcolemma. Membranebound dense secretory granules measuring $70-130 \mathrm{~nm}$ in diameter were the most conspicuous feature of differentiated CMG cells. These granules, thought to be atrial granules, tended to concentrate within the juxtanuclear cytoplasm, with small numbers also located near the sarcolemma. These findings suggest that CMG cells have an ultrastructure consistent with cardiomyocytes.

An electrophysiological study was performed on differ- 
A
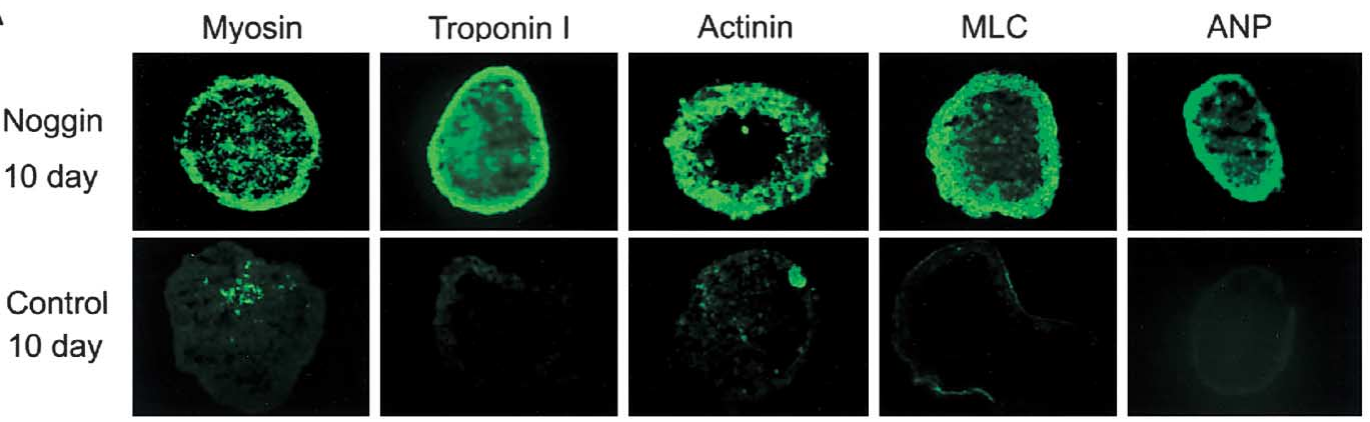

B

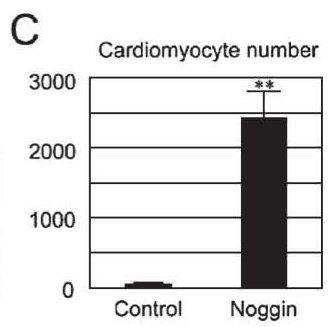

Fig 3. Expression of stem cell markers, cardiac transcription factors and cardiac specific proteins in Noggin-treated embryonic stem cells. (A) Immunostaining for anti-myosin heavy chain (MHC), anti-troponin I, anti-atrial natriuretic peptide (ANP), anti-actinin, and anti-myosin light chain are shown. Most of the cells in the whole embryoid bodies were stained with cardiomyocyte-specific antibodies. (B) Isolated cells were stained with the same antibodies. Red represents nuclear staining with PI. In the last immunofluorescent photograph, ANP, myosine heavy chain and nucleolus are stained with rhodamine, FITC, and DAPI, respectively. (C) Embryoid bodies were attached to the gelatin-coated tissue culture plate, stained with the anti-MHC antibody and examined for the number of cardiomyocytes. The number of cardiomyocytes with Noggin-treated cells was 100-fold more than the control cells. **p<0.01 vs control (Reprinted from Yuasa et al. Nat Biotech 2005; 23: 607-611).

entiated CMG cells 2-5 weeks after 5-azacytidine treatment and 2 types of morphological action potentials were distinguished: sinus node-like potentials (Fig 5A), and ventricular myocyte-like potentials (Fig 5B). The sinus node-like action potential showed a relative shallow resting membrane potential with late diastolic slow depolarization, similar to the potential of a pacemaker. Peak and dome-like morphologies were observed in ventricular myocyte-like cells. A cardiomyocyte-like action potential recorded from these spontaneous beating cells had the following properties: relatively long action potential duration or plateau, relatively shallow resting membrane potential, and a pacemaker-like late diastolic slow depolarization.

Three weeks following azacytidine treatment all action potentials recorded for CMG cells revealed a sinus nodelike action potential. It was not until 4 weeks following azacytidine treatment that ventricular myocyte-like action potentials were initially recorded then found to gradually increase. It is possible that the level of ventricular myocytelike action potentials at 5 weeks was underestimated. Most of the action potentials recorded from differentiated CMG myotubes revealed a ventricular myocyte-like appearance, but were difficult to record. Furthermore, the glass microelectrode was frequently damaged, because the spontaneous contraction of the differentiated myotube at 5 weeks was too large.

Differentiated CMG myotubes expressed both ANP and brain natriuretic peptide (BNP) genes. Table 2 is a summary of the expression of cardiac contractile proteins such as $\alpha-$ and $\beta-M H C, \alpha$-cardiac and $\alpha$-skeletal actin genes. Both $\alpha$ - and $\beta$-MHC expression could be detected by reverse transcriptase-polymerase chain reaction in differentiated CMG cells, but $\beta-\mathrm{MHC}$ expression was overwhelmingly stronger than that of a-MHC. CMG cells expressed both $\boldsymbol{\alpha}$-cardiac and $\mathbf{\alpha}$-skeletal actin. Northern blot analysis revealed that the $\boldsymbol{a}$-skeletal actin gene was expressed at markedly higher levels than the a-cardiac actin gene in CMG cells. Interestingly, CMG cells expressed MLC-2v, but not $-2 \mathrm{a}$.

A number of the characteristics of the CMG cell lines support the cardiomyocyte nature of these cells, including expression of the cardiomyocyte-specific genes ANP, BNP, GATA4 and Nkx2.5. In the ventricular muscle of small mammals there is a developmental switch from expression of $\beta-\mathrm{MHC}$, which is the predominant fetal form, to that of $\mathrm{a}-\mathrm{MHC}$ around the time of birth. There is also a developmental switch from the expression of a-skeletal actin, which is the predominant fetal and neonatal form, to that of $\mathbf{a}$-cardiac actin, the predominant adult form. Differentiated CMG cells express mainly $\beta-\mathrm{MHC}$ and $\alpha$-skeletal actin. Expressions of $\mathrm{-MHC}$ and $\boldsymbol{\alpha}$-cardiac actin were detected, but at low levels. MLC-2 genes are expressed specifically in the heart chamber; MLC- $2 \mathrm{v}$ is expressed specifically in ventricular cells, and MLC-2a is expressed specifically in atrial cells. Differentiated CMG cells express MLC-2v, but not $-2 \mathrm{a}$. These results suggest that differentiated CMG cells have a fetal ventricular cardiomyocyte phenotype.

Although little is known about the induction of the specific pathways of ES differentiation, there are reports of induction of ES cells into cardiomyocytes in vivo ${ }^{36}$ and during coculture with cardiomyocytes 37 An advantage of deriving cardiomyocytes from bone marrow mesenchymal stem cells is that a patient's own cells can be used, thereby overcoming donor rejection problems. A drawback is that, although they appear to self-replicate throughout life in vivo, the number of passages in vitro is limited and at pres- 

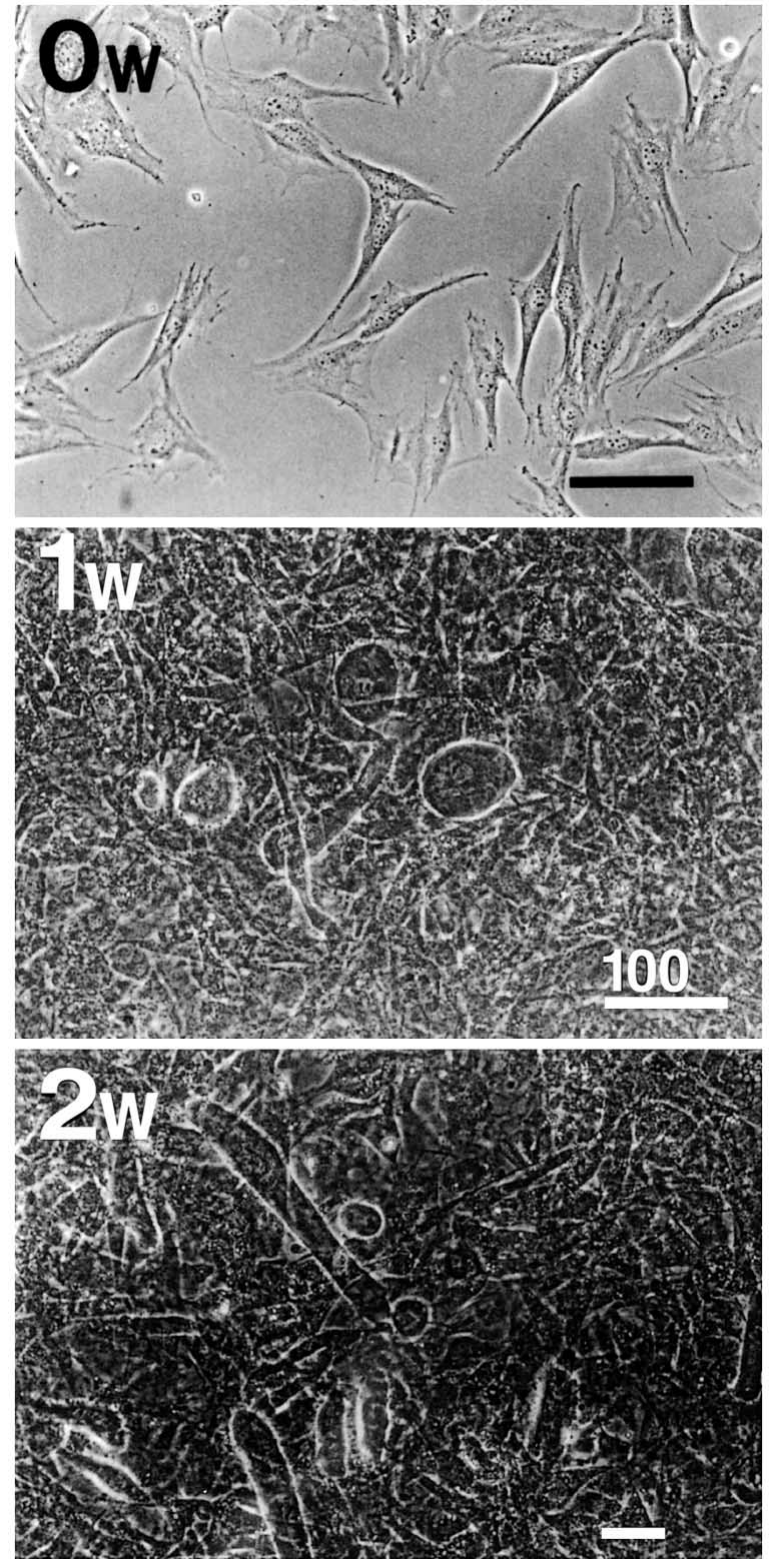

Fig 4. Phase contrast photographs of cardiomyogenic (CMG) cells before and after 5-azacytidine treatment. (Top) CMG cells show fibroblast-like morphology before 5-azacytidine treatment (0 week). (Middle) One week after treatment. Some cells gradually increased in size, became ball-like or stick-like and began to spontaneously beat. (Bottom) Two weeks after treatment. The ball-like or stick-like cells began to form connections with adjoining cells and began to form

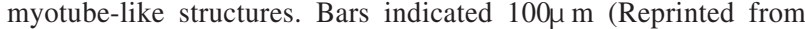
Makino et al. J Clin Invest 1999; 103: 697-705).
(A)

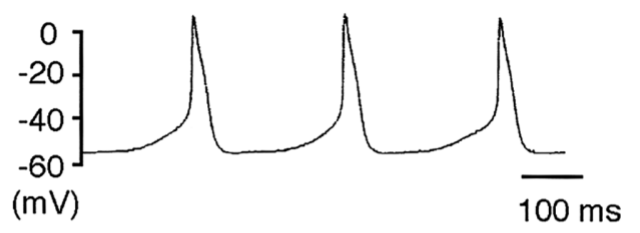

(B)

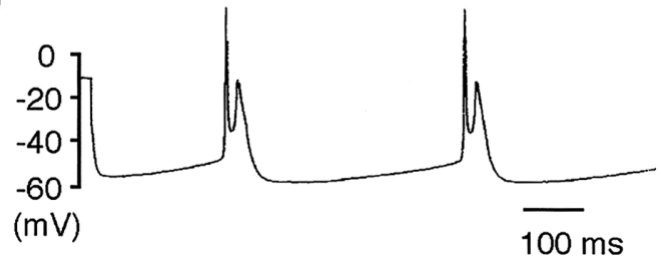

Fig 5. Representative tracing of the action potential of cardiomyogenic myotubes. Action potential recordings were obtained from spontaneously beating cells at day 28 after 5-azacytidine treatment using a conventional microelectrode. These action potentials were categorized into 2 groups: sinus node-like action potential (A) and ventricular cardiomyocyte-like action potential (B) (Reprinted from Makino et al. J Clin Invest 1999; 103: 697-705).

ent it is not possible to culture bone marrow mesenchymal stem cells in large quantities. Cardiomyocytes that differentiate from bone marrow mesenchymal stem cells initially assume the phenotype of embryonic ventricular myocardium, but they gradually mature and eventually exhibit adult-type gene expression 3,4 They also express functioning sympathetic and parasympathetic nerve receptors, consistent with cardiomyocytes in vivo 38

\section{Cardiac-Specific Stem Cells}

C-kit-positive or Sca-1 (stem cell antigen-1)-positive cells derived from heart tissue are capable of differentiating into cardiomyocytes, 5 These cells are thought to be heartspecific stem cells and to differentiate into cardiomyocytes, smooth muscle cells, and vascular endothelial cells. C-kitpositive and Sca-1-positive cells not only have different characteristics, their capacity to differentiate also differs. These cells have the ability to proliferate to some extent in vitro, and they are regarded as a useful tool for regenerating cardiomyocytes. The C-kit antigen is a cytokine stem-cellfactor receptor also present in humans. Sca-1, on the other hand, is a mouse-specific antigen, and humans do not possess any corresponding antigen, making it difficult to apply this marker to humans. The rarity of cardiac-specific stem cells makes them difficult to isolate from biopsy specimens and poses a problem for their future clinical application.

A side population (SP) of stem cells in the heart that did not express MHC and rapidly decreased from 4 days after birth was recently characterized 99 Fluorescence-activated cell sorter (FACS) analysis revealed the following marker profile: Ter119-, CD45-, CD13-, CD11b-, CD29+', CD44+,

Table 2 Expression of the Isoforms of the Cardiac Contractile Proteins in CMG Cell

\begin{tabular}{|c|c|c|c|c|c|c|}
\hline & \multicolumn{2}{|c|}{ Atrium } & \multicolumn{3}{|c|}{ Ventricle } & \multirow{2}{*}{$C M G$} \\
\hline & Fetal & Adult & Fetal & Neonatal & Adult & \\
\hline a-actin & Skeletal & Cardiac & $\begin{array}{c}\text { Skeletal }>\text { Cardiac } \\
\beta\end{array}$ & Skeletal & Cardiac & Skeletal $>$ Cardiac \\
\hline$M L C$ & $2 a$ & $2 a$ & $2 v$ & $2 v$ & $2 v$ & $2 v$ \\
\hline
\end{tabular}

$C M G$, cardiomyogenic cell; $M H C$, myosin heavy chain; $M L C$, myosin light chain. 

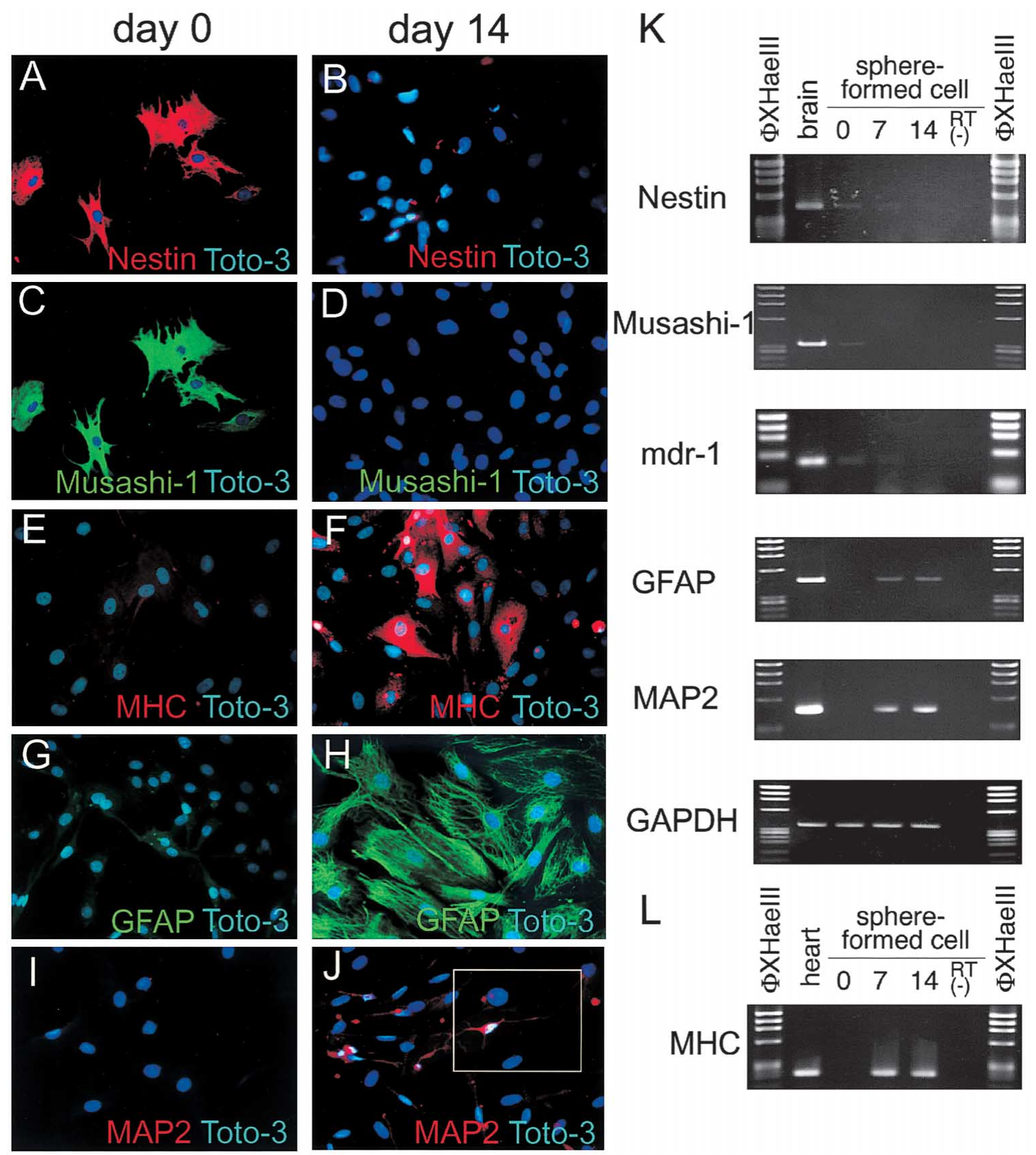

Fig 6. Differentiation of cardiosphere-derived cells in vitro. Cardiospheres were obtained from P2 neonates. Dissociated cardiosphere-derived cells were maintained in medium without epidermal growth factor and fibroblast growth factor- 2 . At day 0, almost all cells stained with anti-nestin (A) and anti-Musashi-1 antibodies (C), but did not stain with antisarcomeric myosin (MF20) (E, F), anti-GFAP (G), or anti-mitgen activated protein (MAP) 2 (I) antibodies. At day 14, the cells did not stain with anti-nestin (B), or anti-musashi-1 (D) antibodies. By comparison, some cells stained with either anti-sarcomeric myosin (F), anti-GFAP (H), or anti-MAP2 (J) antibodies. The square box in (J) is enlarged in Fig 3C. (K) Reverse transcriptase-polymerase chain reaction (RT-PCR) analyses of nestin, musashi-1, mdr-1, GFAP and MAP2. Note that cardiosphere-derived cells at day 0 express nestin, musashi- 1 and mdr-1, but not GFAP or MAP2. By comparison, these stem cell markers disappeared at day 14, and cells began to express GFAP and MAP2. (L) RT-PCR analysis of $\beta$-myosin heavy chain $\beta$-MHC). Fetal brain or heart was used as a positive control (Reprinted from Tomita et al. J Cell Biol 2005; 170: $1135-1146$.

c-kit ${ }^{\text {low }}, \mathrm{CD} 34^{\text {low }}, \mathrm{CD} 49 \mathrm{e}^{-/ \text {low }}, \mathrm{CD} 49 \mathrm{e}^{\text {low }}$, flk-1- low and Sca-1- $1^{- \text {low }}$. Less than $1 \%$ of the cardiac SP cells formed floating spheroid colonies upon clonal expansion in serumfree media containing FGF-2 and epidermal growth factor. Immediately after dissociation cells from these spheroid colonies expressed markers of neural precursor cells, in- cluding nestin, musashi-1 and the p75 nerve growth factor receptor. After 14 days in the presence of media containing $0.5 \%$ serum, they ceased to express nestin or musashi-1 and some of the cells expressed the neural differentiation markers MAP-2, peripherin, Neu N, Hu and P0. Another cell type expressed the cardiac-specific genes $\mathrm{Nkx} 2.5$, 

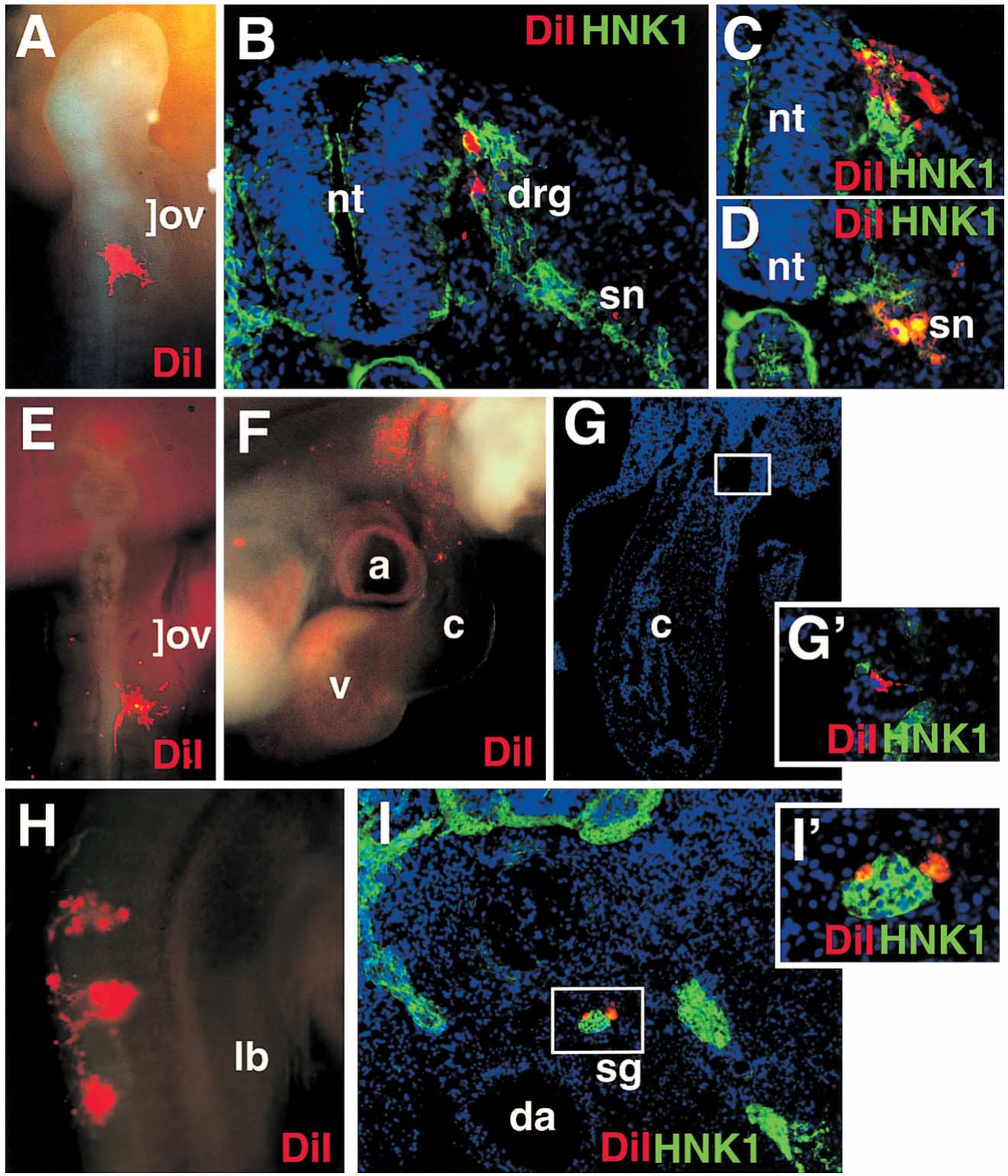

Fig 7. Cardiosphere cells behave as neural crest in the chicken embryonic environment. Cardiospheres obtained from P2 neonates were labeled with DiI and transplanted into the chick neural crest. (A) Dorsal view of a chicken embryo that received cardiosphere cells into the MSA at the second somite level. Cardiosphere-derived cells well dispersed $24 \mathrm{~h}$ after transplantation. (B,C) Transverse sections of cardiosphere-transplanted embryos, stained with the HNK1 antibody specific for neural crest-derived cells and with DAPI to detect nuclei. DiI-labeled cardiosphere-derived cells contribute to the developing dorsal root ganglia (drg, b), and spinal nerve (sn, D). Many sphere-derived cells also enter the lateral migration pathway (C). (E) Dorsal view of a chicken embryo that received DiI-labeled cardiosphere cells into the lateral pathway at the second somite level. (F) Side view of an embryo at $48 \mathrm{~h}$ after transplantation into the lateral pathway, showing the developing heart. Many cardiosphere-derived cells are entering the outflow tract area. (G) Transverse section of the transplanted embryo, showing the outflow tract and conotruncal region. (G') Higher magnification of the boxed area in $(\mathrm{G})$. Both a DiI-labeled sphere-derived cell and a HNK1-positive host-derived crest cell are visible. $(\mathrm{H})$ Dorso-lateral view of an embryo that received 3 cardiosphere cells into the MSA at the wing limb bud level, $48 \mathrm{~h}$ after transplantation. (I) Transverse section of the transplanted embryo, showing developing sympathetic ganglia (sg). (I') Higher magnification of the boxed area in (I), stained with HNK1 and DAPI. Cardiosphere-derived cells are integrated into the ganglia. a, atrium; c, conotruncal; da, dorsal aorta; drg, dorsal root ganglia; lb, limb bud; nt, neural tube; ov, otic vesicle; sg, sympathetic ganglia; sn, spinal nerve; v, ventricle (Reprinted from Tomita et al. J Cell Biol 2005; 170: 1135-1146.

GATA4, MEF2C, ANP, Cav1.2 anda -skeletal actin, and a few showed spontaneous beating (Fig 6). These cells displayed a sinus node-like action potential. Other cells expressed GFAP or calponin and a-smooth muscle actin, indicating glial and smooth muscle differentiation. These results suggest that the cardiosphere-forming population of cardiac SP cells are multipotent with the capacity to differentiate into neurons, glial cells, smooth muscle cells, and cardiomyocytes, and appear to have neural crest-like characteristics.

The neural crest-like characteristics of the cardiosphereforming population of cardiac SP cells was investigated in 

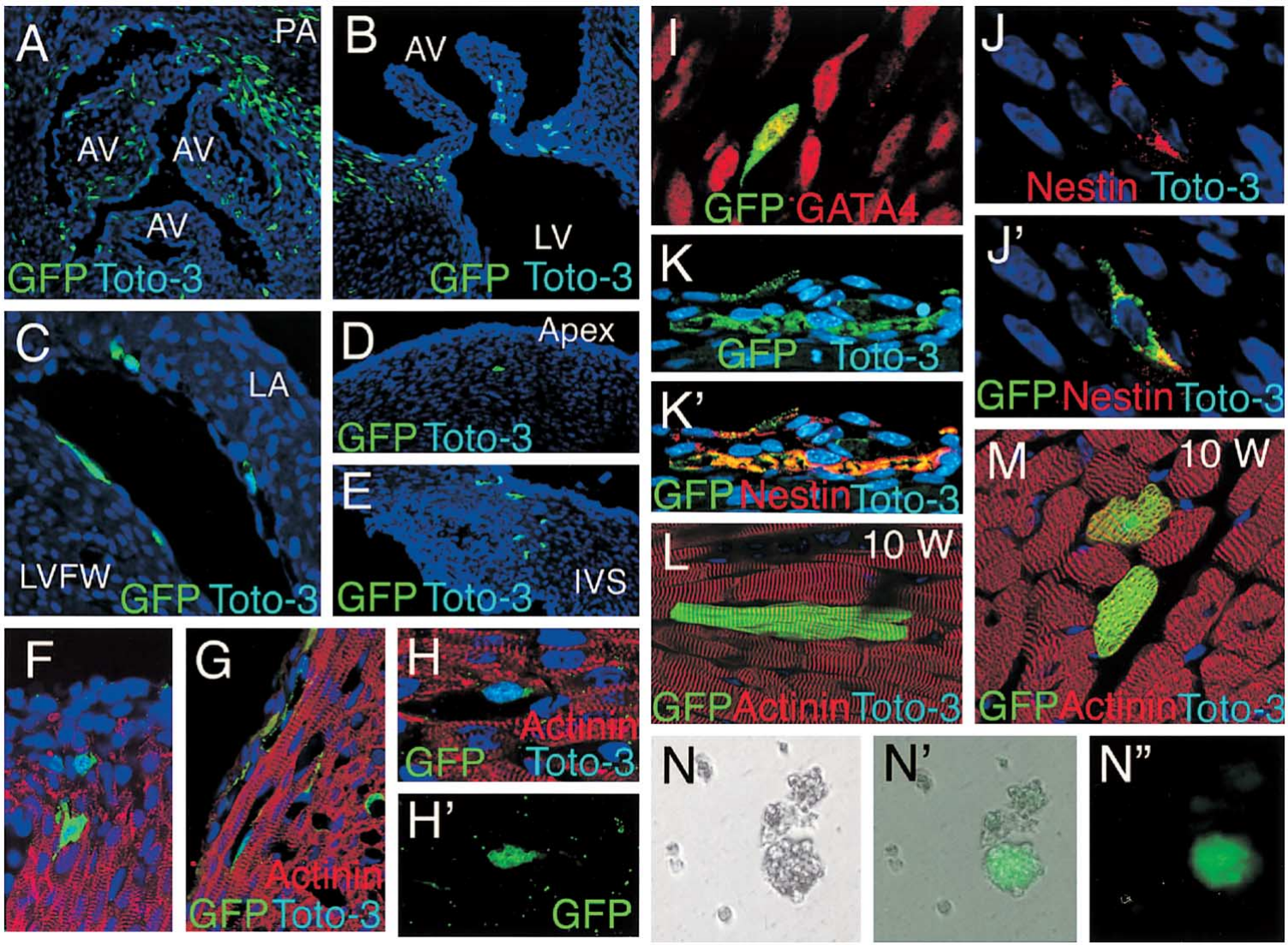

Fig 8. Distribution and co-immunostaining of neural crest derived cells in the heart. (A-E) P0 Cre/CAG-CAT-EGFP double transgenic $(\mathrm{Tg})$ mice heart was immunostained with TOTO-3 and anti-GFP antibody. EGFP+ cells are concentrated in the outflow tract and aortic valve (A,B), and are also observed in the subepicardial layer (C) and intramuscular layer $(\mathrm{D}, \mathrm{E})$ of the ventricles. EGFP+ ${ }^{+}$cells can be seen at the free wall $(\mathrm{C})$, apex (D), interventricular septum $(\mathrm{E})$ and atrium $(\mathrm{C})$. (F-H) Triple-immunostaining for actinin (red), GFP (green) and TOTO-3 in E17.5 P0-Cre/CAG-CAT-EGFP double Tg mice heart. EGFP+ cells did not stain with actinin. $(\mathrm{H})$ and $\left(\mathrm{H}^{\prime}\right)$ show the same field. (I) Double-immunostaining for GATA4 (red), and GFP (green) in E17.5 double Tg mice heart. Some of the EGFP+ cells are stained with the antiGATA4 antibody. (J,K) Triple-immunostaining for nestin (red), GFP (green) and TOTO-3 (blue) in E17.5 double Tg mice heart. $\mathrm{EGFP}^{+}$cells were stained with anti-nestin antibody. (JJ') and (KK') show the same field, respectively. (L,M) Tripleimmunostaining for actinin (red), GFP (green) and TOTO-3 in 10-week-old adult P0-Cre/CAG-CAT-EGFP double Tg mice heart. EGFP+ cells express actinin with complete striation that indicates cardiomyocytes. (N,N") Cardiosphere isolated from 10-week-old adult P0-Cre/CAG-CAT-EGFP double Tg mice heart shows EGFP signals, indicating that they are derived from neural crest cell (Reprinted from Tomita et al. J Cell Biol 2005; 170: 1135-1146.

vivo by transplanting the cells to the neural crest of the chick embryo. These cells were found to migrate with hostderived neural crest cells and contribute to cells of the developing peripheral nervous system, such as the dorsal root ganglion and the ventral spinal nerve (Fig 7). They also entered the lateral migration pathway, normally taken by ectomesenchymal cells that are neural crest-derived melanocyte precursors. When transplanted directly into the lateral migration pathway, the cardiosphere-forming population of cardiac SP cells successfully entered the outflow tract and conotruncus of the developing heart. Some of these cells expressed the neuronal marker $\mathrm{Hu}$, and fewer expressed the glial marker GFAP. This analysis also revealed a population of these cells that contributed to major blood vessels and expressed smooth muscle actin. The contribution of the cardiosphere-forming population of cardiac SP cells to the neural crest-derived tissues in the chick embryo is consistent with the neural crest stem cell characteristics displayed by these cells.

The contribution of neural crest-derived cells to the cardiac multipotential stem cell population was investigated.
For analysis of the neural crest cell lineage, Yamauchi et al crossed P0-Cre transgenic mice with CAG-CAT-Z indicator transgenic mice, which carry a LacZ gene downstream of a chicken-actin promoter and a "stuffer" fragment flanked by 2 loxP sequences $4^{40}$ In 3 different transgenic lines lacZ expression was observed in tissues derived from neural crest cells, including spinal dorsal root ganglia, the sympathetic nervous system, the enteric nervous system, and ventral craniofacial mesenchyme at stages later in development than E9.0.

Trangenic mice carrying the $\mathrm{P} 0$-Cre recombinase and CAG-CAT-EGFP transgenes showed EGFP expression in tissues derived from neural crest cells, including spinal dorsal root ganglia, the sympathetic nervous system, the enteric nervous system, and ventral craniofacial mesenchyme. $\mathrm{EGFP}^{+}$cells were concentrated at the outflow tract between aorta and pulmonary artery, and aortic valves. They were also observed at the intramuscular and subepicardial layer of both ventricles, including the intraventricular septum, free wall and apex (Fig 8), and the atrial wall. Triple immunostaining of the E17.5 heart showed a lack of staining of 

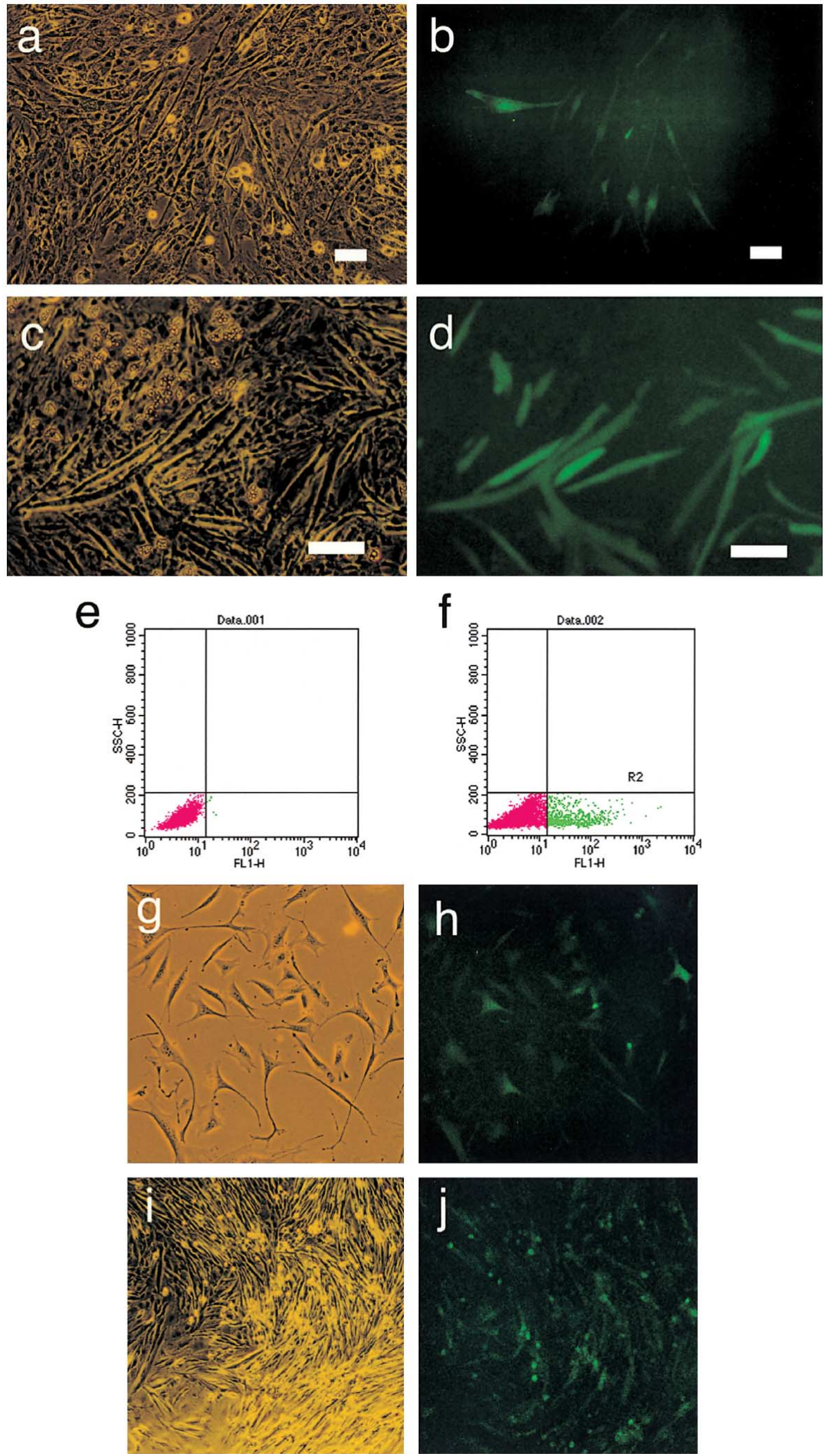

Fig 9. Isolation of regenerated cardiomyocytes. Bone marrow mesenchymal stem cells were transfected with EGFP under the control of the promoter of a ventricular-myocardium-specific protein, myosin light-chain $2 \mathrm{v}$, and induced to differentiate. Some of the cells are green fluorescent protein (GFP)-positive 7 days after differentiation (a,b), and have started beating at 3 weeks $(\mathrm{c}, \mathrm{d})$. When the cells were fractionated with a FACS cell sorter after becoming GFP-positive (e,f), only cardiomyocytes were obtained (g-j). (g,h) At 4 days, and (i,j) 3 weeks after cell sorting. (Reprinted from Hattan et al. Cardiovasc Res 2005; 65: 334-344 with some modification). 

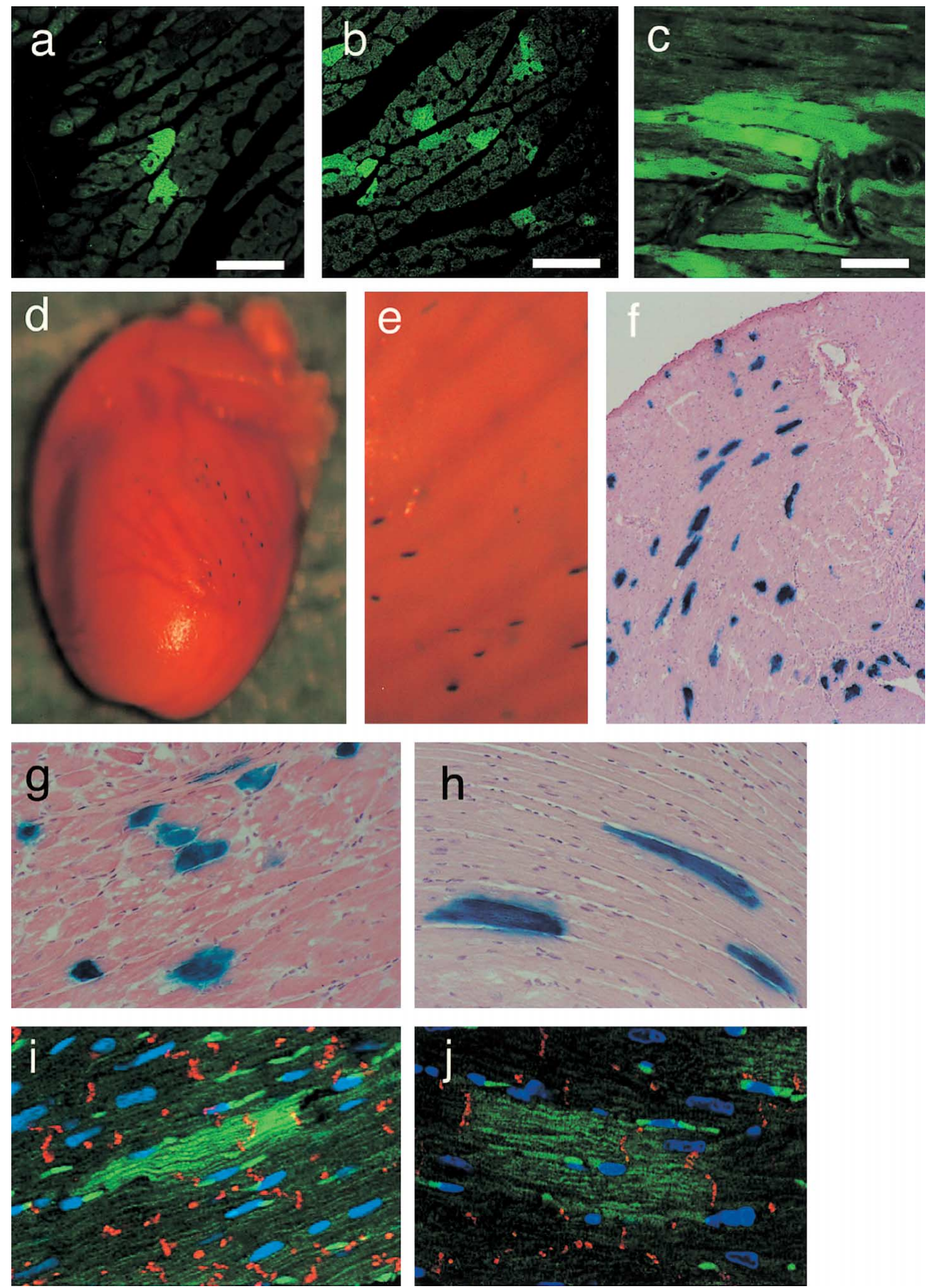

Fig 10. Transplantation of regenerated cardiomyocytes. Regenerated cardiomyocytes (see Fig 2) transplanted into adult mice hearts with a syringe. This experiment confirms that transplanted cardiomyocytes stably reside in the heart and can survive for a long time. Once injected the regenerated cardiomyocytes diffuse into the heart-like islands then closely adhere to surrounding cardiomyocytes and assume the form of mature cardiomyocytes that have the appearance of short strips of paper. $(\mathrm{a}-\mathrm{c})$ Cells in which there is green fluorescent protein (GFP) fluorescence, $(\mathrm{d}-\mathrm{h})$ transfected with LacZ and stained. When these cells were co-immunostained for connexin 43 , they were observed to have formed gap junctions with the surrounding cardiomyocytes $(i, j)$. The green is GFP, the blue is nuclear staining with TOTO-3, and the red represents connexin43 (Reprinted from Hattan et al. Cardiovasc Res 2005; 65: 334-344 with some modification). 
a

웅ㅇ
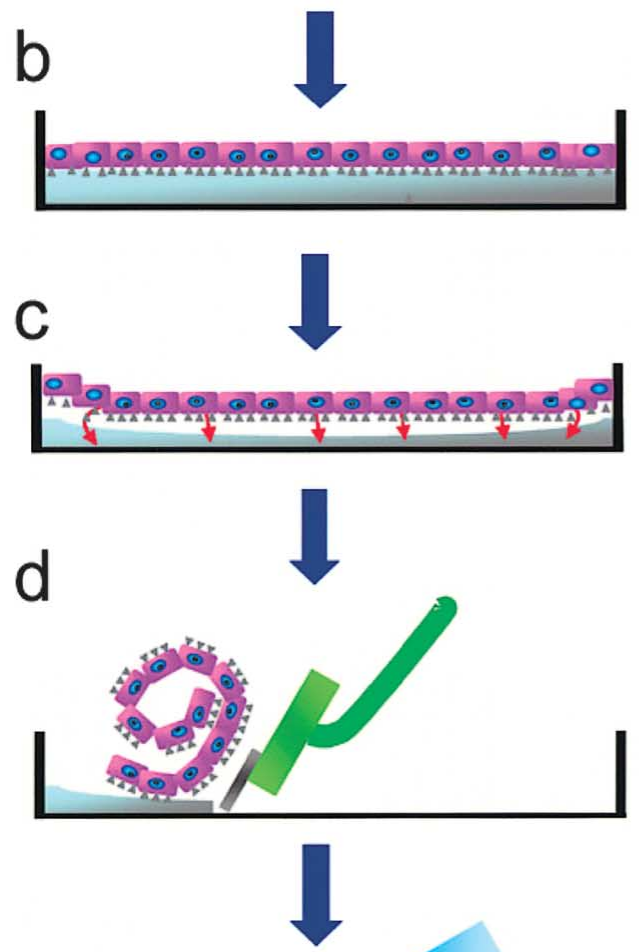

e
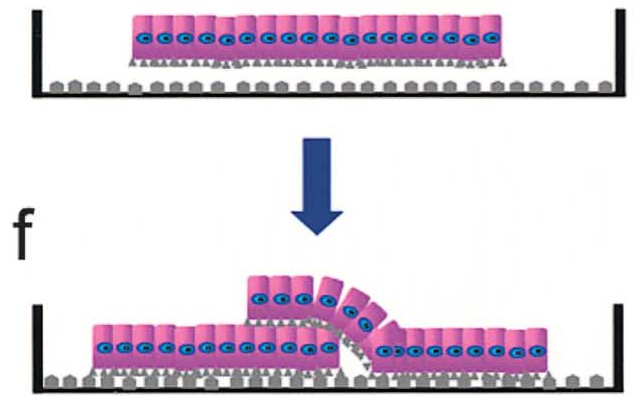

9

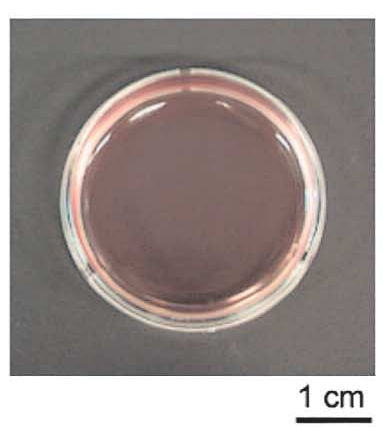

h

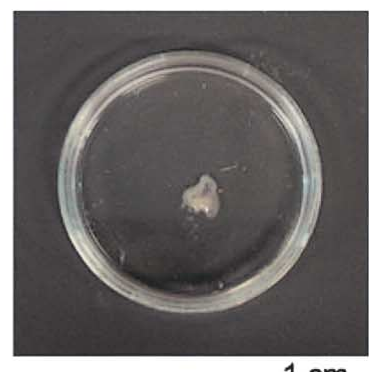

$1 \mathrm{~cm}$
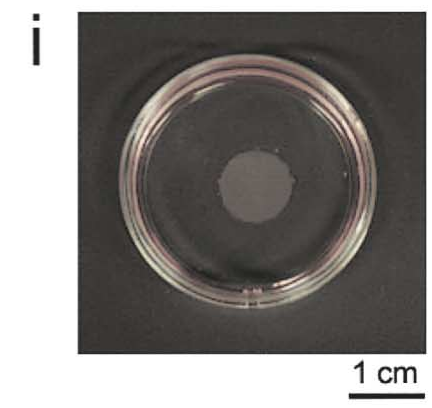

j

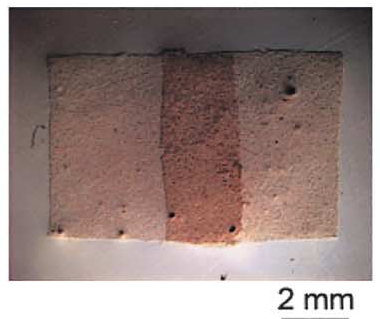

k

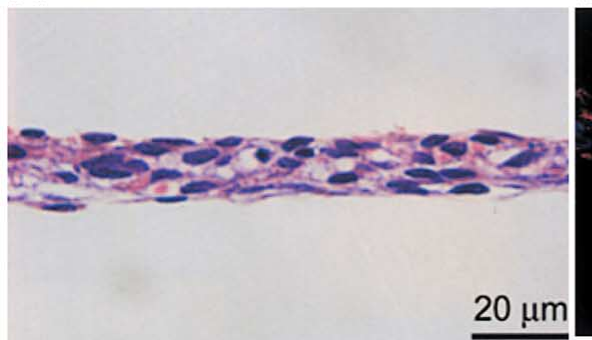

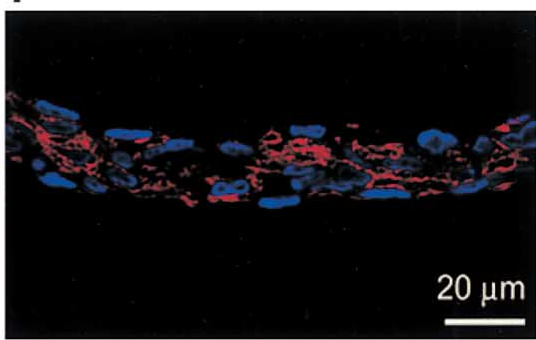

Fig 11. Production of myocardial cell sheets using culture dishes coated with a fibrin polymer membrane. The fibrin polymer is gradually degraded by various endogenous proteases secreted by the cardiomyocytes, making it easy to peel the sheet off the surface of the dish. This can be used to conveniently produce cardiomyocyte sheets. (a-f) Schema, $(\mathrm{g}-\mathrm{j})$ actual process, $(\mathrm{k}, \mathrm{l})$ sheets stained with hematoxylin-eosin and immunofluorescence respectively. Red, actinin; Blue, Toto-3; Green, fibrin (Reprinted from Itabashi et al. Artif Org 2005; 29: 95-103). 

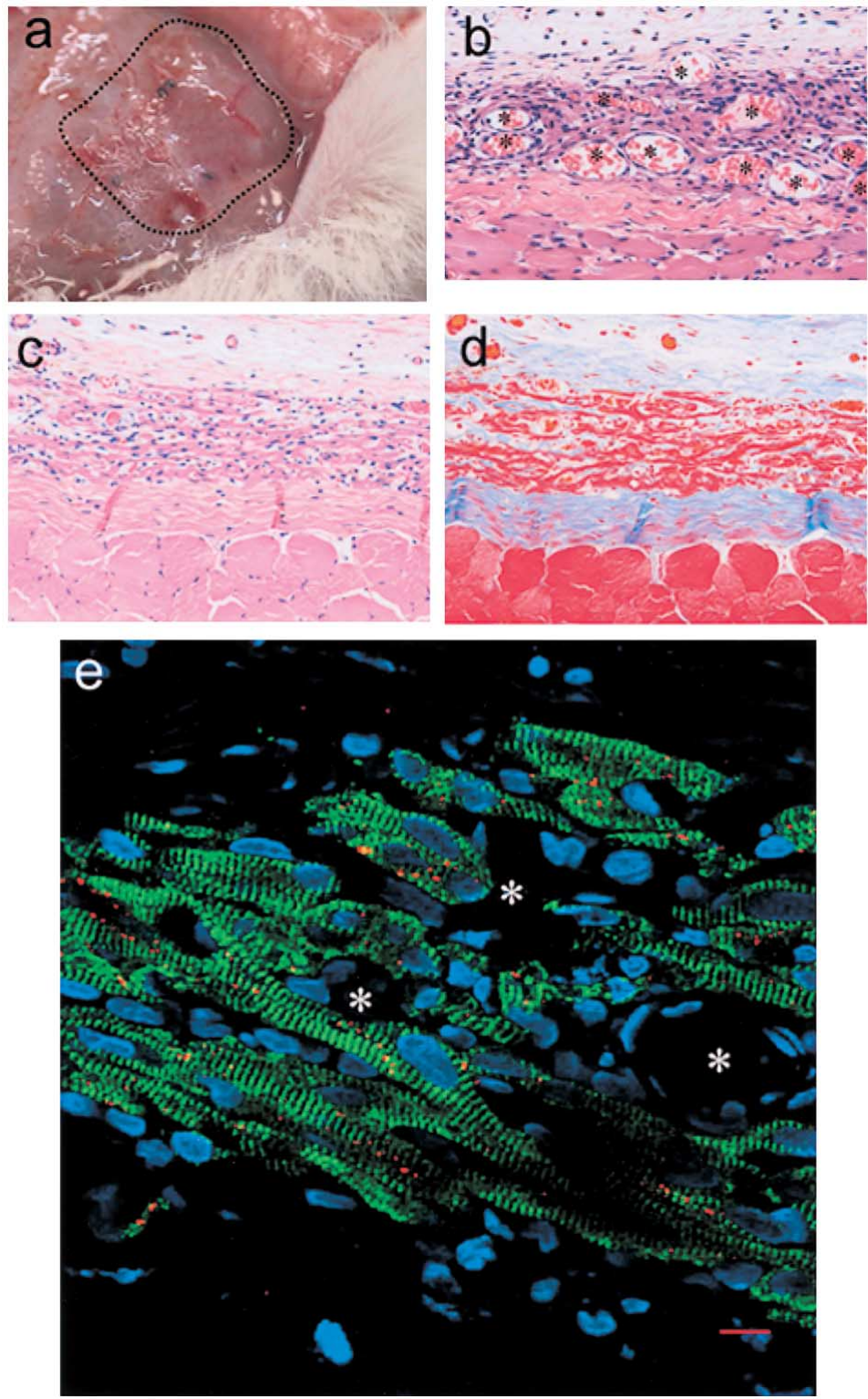

Fig 12. Subcutaneous transplantation of cardiomyocyte sheets. (a) External view, (b-e) histological views. (b,c) Hematoxylin-eosin staining; (d) Azan staining; (e) immunofluorescence staining. Green, actinin; red, connexin43; blue, nuclei stained with TOTO-3 (Reprinted from Itabashi et al. Artif Org 2005; 29: 95-103).
$\mathrm{EGFP}^{+}$cells with anti-actinin antibody, but positive staining with anti-GATA4 and anti-nestin antibodies. In 10-weekold hearts triple immunostaining demonstrated that some $\mathrm{EGFP}^{+}$cells were clearly actinin ${ }^{+}$cardiomyocytes. This result was supported by the finding that cardiospheres obtained from 10-week-old double transgenic mice hearts clearly express EGFP. These findings strongly suggest that neural crest-derived cells contribute to various cell types in 10 -week-old mice, including cardiomyocytes, that may persist in the adults.

\section{Cardiomyocyte Transplantation}

The concept of cardiomyocyte transplantation has been

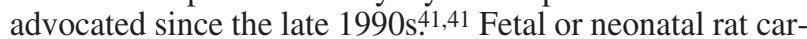
diomyocytes have been successfully transplanted into the hearts of adult rats and transplanted cells are viable within the heart for relatively long periods, forming gap junctions with surrounding recipient cells. Prior to the transplantation of pluripotent ES cell-derived cardiomyocytes into the heart, undifferentiated cells, and cells that have differenti- ated into other cell types, must be eliminated. Methods that use a cell sorter or drug-resistant genes to collect ES cellderived cardiomyocytes have been reported.2-45 These include methods that specifically label cardiomyocytes by introducing into ES cells, for example, green fluorescent protein (GFP) with a cardiomyocyte-specific promoter. In a previous study GFP was placed under the control of the myosin light-chain gene promoter and introduced into bone marrow mesenchymal stem cells. ${ }^{46}$ Fig 9 shows that when these cells are induced to differentiate, only cardiomyocytes produce the GFP signal and can be collected to a purity of more than $99 \%$ with a FACS cell sorter. When these cells were transplanted using a syringe into the hearts of syngeneic mice they moved into the gaps between recipient cardiomyocytes (Fig 10), became connected to surrounding cells via gap junctions, and resided stably in the heart for a long period of time. 46 This result shows the potential of regenerated cardiomyocytes as an alternative to fetal or neonatal cardiomyocytes for transplantation.

Although transplanting cells with a syringe is a simple technique, the disadvantages of this method that preclude 
a
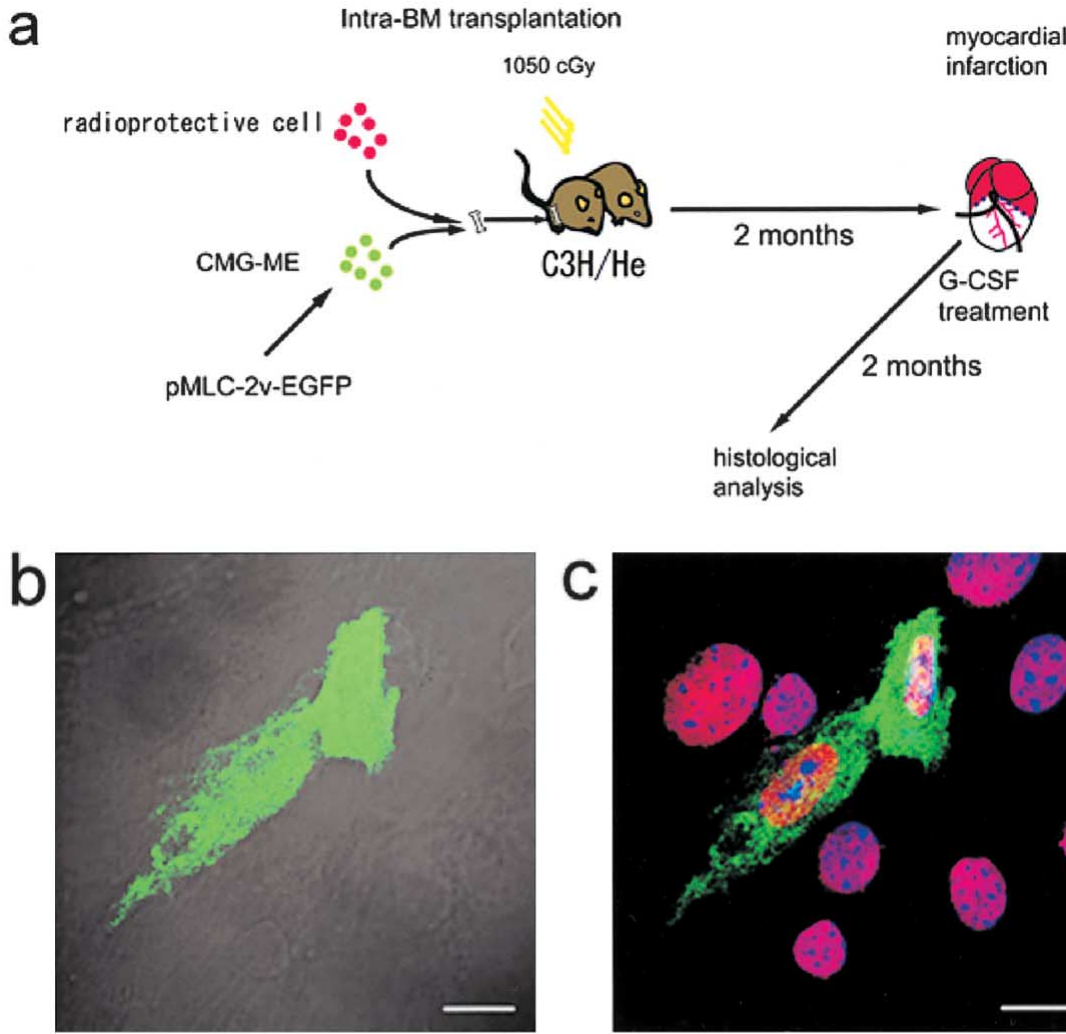

C

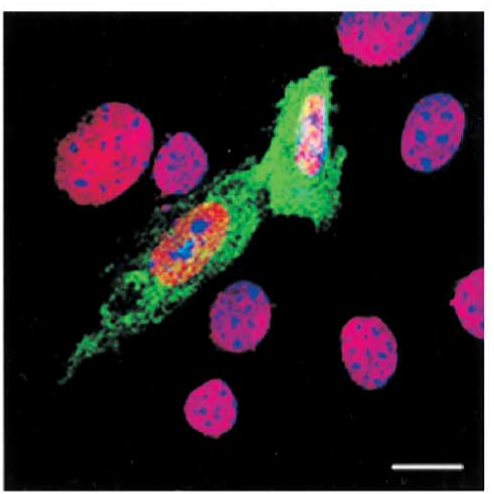

d

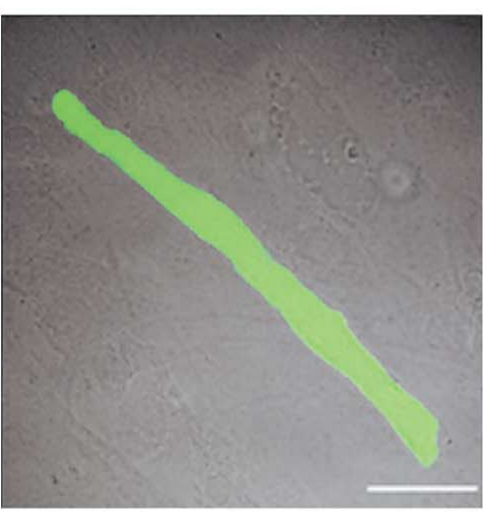

e
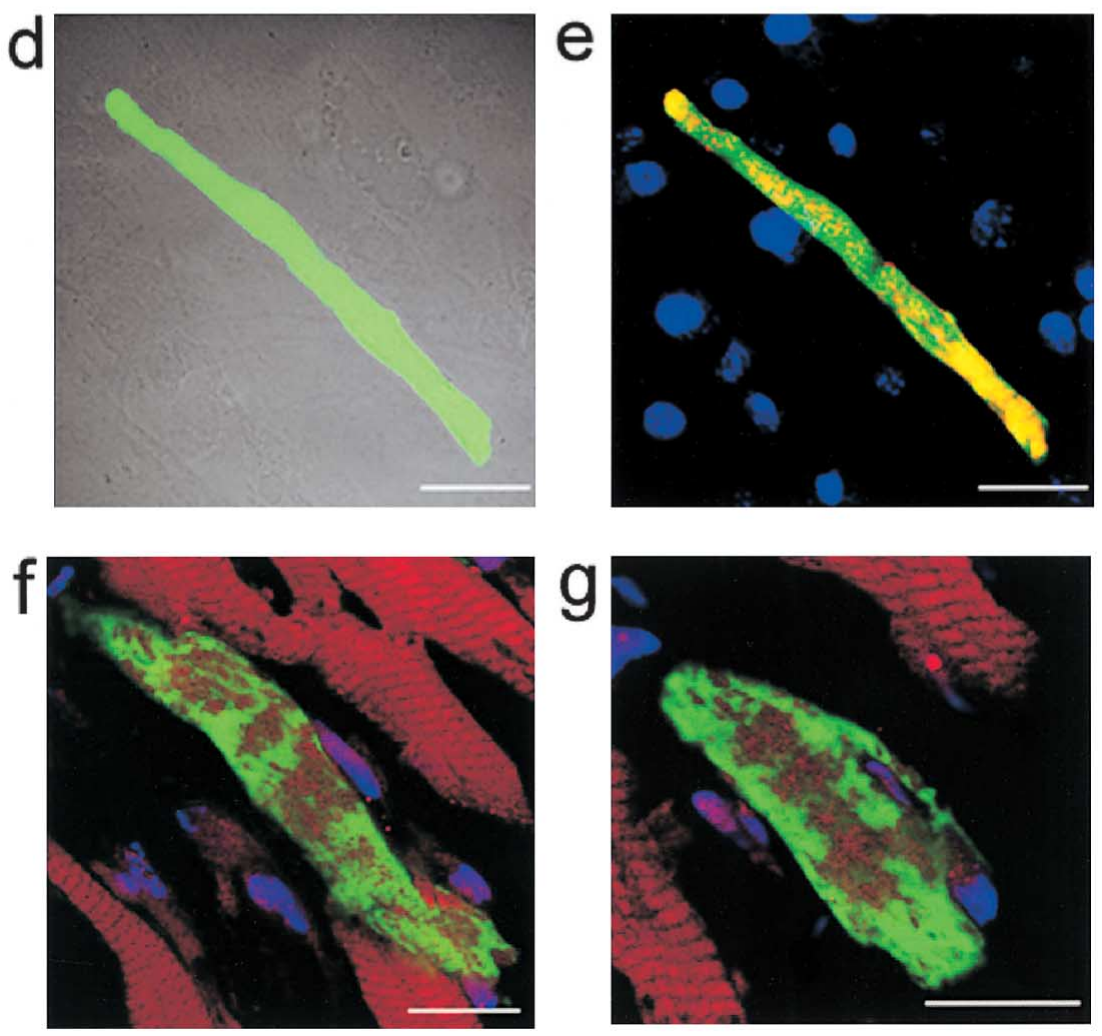

\section{g}

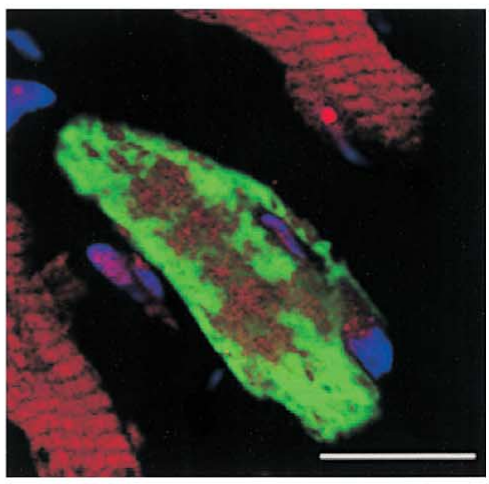

Fig 13. Bone marrow mesenchymal stem cells can be mobilized and differentiate into cardiomyocytes after myocardial infarction in vivo. (a) Experimental protocol. The plasmid described in Fig 2 was transfected into bone marrow mesenchymal stem cells, and intra-bone marrow bone marrow transplantation (IBM-BMT) was performed in mice exposed to a lethal dose of radiation. Myocardial infarction was induced in the mice 3 months after the bone marrow had been reconstructed, and the infarct focus was examined. (b-e) Differentiation of cardiomyocyte in vitro. EGFP positive cells expressed GATA-4 (c) and cardiac actinin (e). (f, g) The gene-marked mesenchymal stem cells were mobilized to the infarcted foci and differentiated into cardiomyocytes (Reprinted from Kawada et al. Blood 2004; 104: 35813587). its clinical application include the inability to transplant large numbers of cells and the low viability of transplanted cells. To improve the clinical applicability of cardiomyocyte transplantation technology Okano and coworkers produced temperature-sensitive resin coated culture dishes.
The surface of these dishes becomes hydrophilic when the temperature is lowered, so cultured cardiomyocytes can be peeled off in sheets.8,48 Using this approach, another method of producing cardiomyocyte sheets (Fig 11) was developed in my laboratory 50 This new method uses poly- 
merized fibrin (fibrin glue) normally used in surgical operations. A thin fibrin polymer membrane on the surface of the culture dish is generated by reacting fixed concentrations of fibrinogen and thrombin. When cardiomyocytes are cultured on these dishes, they secrete a variety of endogenous proteases that break down the fibrin polymer membrane in approximately 3 days, making it possible to obtain cardiomyocytes in sheets. After 7 days of culture the fibrin is completely removed. Transplantation of the cardiomyocyte sheets is characterized by good cell viability and residence rates (Fig 12). Most studies report that less than $10 \%$ of cardiomyocytes transplanted using a syringe reside stably in the heart, whereas few cells are lost after transplantation in which the cardiomyocyte sheets are transplanted subcutaneously. A further advantage of using cardiomyocyte sheets is that they can be layered to varying tissue thicknesses. These findings support myocardial sheet formation as an important tool in future cell transplantation technology. The efficient clinical application of this technique requires progress in the stimulation of vascularization. Although transplantation is followed by the formation of a microvascular network, large blood vessels do not form.

\section{Myocardial Regeneration From Stem Cells in Adults}

Research thus far has demonstrated that bone marrow stem cells differentiate into cardiomyocytes in vitro, but it is unknown if they migrate into the heart and differentiate into cardiomyocytes in vivo 51 The pluripotency of hematopoietic stem cells and cell fusion by pluripotent stem cells have been investigated over the past 2 years ${ }^{52-54}$ There is confusion in the literature over the mechanism of in vivo repair by bone marrow cells. For this reason an analysis using an in vivo murine bone marrow transplantation model was performed to verify the formation of cardiomyocytes by any of the cells in bone marrow (hematopoietic stem cells or mesenchymal stem cells) 55 In this analysis GFPmarked hematopoietic and mesenchymal stem cells were transplanted separately into allogeneic mice exposed to a lethal dose of radiation. single hematopoietic stem cells were then harvested from GFP transgenic mice by FACS, using a technique called the KSL-SP method, and transplanted together with radioprotective cells responsible for hematopoiesis that were not labeled with GFP. In addition, mesenchymal stem cells were labeled so that they would express GFP when differentiated into cardiomyocytes. Transplantation was performed using intra-bone marrow bone marrow transplantation. This method was chosen to avoid the possibility of the transplanted mesenchymal stem cells, which are larger in diameter than hematopoietic stem cells, of becoming trapped in the lungs and other tissues. Myocardial infarction was induced in the mice transplanted with hematopoietic or mesenchymal stem cells, and their hearts were analyzed 2 months later. In mice transplanted with hematopoietic stem cells, GFP-positive cells were rare and appeared at the same frequency as previously reported for cell fusion. By comparison, the mice transplanted with mesenchymal stem cells showed actinin-staining GFPpositive cells at the infarct foci. These results suggest that mesenchymal stem cells are mobilized from the bone marrow when there is an injury associated with necrosis of myocardial tissue, such as in myocardial infarction, and that mesenchymal stem cells are capable of differentiating into cardiomyocytes at the infarct foci. The cytokine granu- locyte-colony stimulating factor (G-CSF) was administered at the time when the stem cells are mobilized from bone marrow, because there was a large difference in the number of regenerated cardiomyocytes between the control group and the G-CSF group. G-CSF was demonstrated to not only mobilize hematopoietic stem cells in the blood stream, as previously known, but to have the capacity to mobilize mesenchymal stem cells (Fig 13).

Although G-CSF is used clinically to some extent, evaluations are yet to be concluded. ${ }^{56,57}$ Furthermore, it is unclear if mesenchymal stem cells are mobilized in humans to the same extent as in mice and whether they have the clinical potential for regeneration of heart damage following myocardial infarction. Further studies are necessary to elucidate the molecular mechanism of action of G-CSF before its clinical potential can be fully realized.

\section{Conclusion}

The concept of "myocardial regeneration therapy for heart failure" is very appealing, but it must be founded on solid basic research and should be evaluated objectively. Stem cell research has proceeded at a rapid pace, and it may soon become possible to produce large numbers of cardiomyocytes from ES cells, or mesenchymal stem cells, or both. It is also likely that cytokine therapy will be performed clinically in the near future. Examination of the present state of affairs in transplantation research is a reminder that deeper understanding is needed.

\section{References}

1. Beltrami AP, Urbanek K, Kajstura J, Yan SM, Finato N, Anversa P, et al. Evidence that human cardiac myocytes divide after myocardial infarction. N Engl J Med 2001; 344: 1750-1757.

2. Yuasa S, Fukuda K, Tomita Y, Fujita J, Ieda M, Tahara S, et al. Cardiomyocytes undergo cells division following myocardial infarction is a spatially and temporally restricted event in rats. Mol Cell Biochem 2004; 259: 177-1781.

3. Makino S, Fukuda K, Miyoshi S, Konishi F, Kodama H, Pan J, et al. Cardiomyocytes can be generated from marrow stromal cells in vitro. J Clin Invest 1999; 103: 697-705.

4. Fukuda K. Development of regenerative cardiomyocytes from mesenchymal stem cells for cardiovascular tissue engineering. Artif Org 2001; 25: 187-193.

5. Beltrami AP, Barlucchi L, Torella D, Baker M, Limana F, Anversa $\mathrm{P}$, et al. Adult cardiac stem cells are multipotent and support myocardial regeneration. Cell 2003; 114: $763-776$.

6. Oh H, Bradfute SB, Gallardo TD, Nakamura T, Gaussin V, Schneider $\mathrm{MD}$, et al. Cardiac progenitor cells from adult myocardium: Homing, differentiation, and fusion after infarction. Proc Natl Acad Sci USA 2003; 100: $12313-12318$.

7. Jiang Y, Jahagirdar BN, Reinhardt RL, Schwartz RE, Keene CD, Verfaillie CM, et al. Pluripotency of mesenchymal stem cells derived from adult marrow. Nature 2002; 418: 41-49.

8. Jiang Y, Vaessen B, Lenvik T, Blackstad M, Reyes M, Verfaillie CM. Multipotent progenitor cells can be isolated from postnatal murine bone marrow, muscle, and brain. Exp Hematol 2002; 30: 896-904.

9. Thomson JA, Itskovitz-Eldor J, Shapiro SS, Waknitz MA, Swiergiel JJ, Jones JM, et al. Embryonic stem cell lines derived from human blastocysts. Science 1998; 282: 1145-1147.

10. Kehat I, Kenyagin-Karsenti D, Snir M, Segev H, Amit M, Gepstein L, et al. Human embryonic stem cells can differentiate into myocytes with structural and functional properties of cardiomyocytes. J Clin Invest 2001; 108: 407-414.

11. Schultheiss TM, Burch JB, Lassar AB. A role for bone morphogenetic proteins in the induction of cardiac myogenesis. Genes Dev 1997; 11: $451-462$.

12. MimaT, Ueno H, Fischman DA, Williams LT, Mikawa T. Fibroblast growth factor receptor is required for in vivo cardiac myocyte proliferation at early embryonic stages of heart development. Proc Natl Acad Sci USA 1995; 92: 467-471.

13. Fraidenraich D, Stillwell E, Romero E, Wilkes D, Manova K, 
Benezra R, et al. Rescue of cardiac defects in id knockout embryos by injection of embryonic stem cells. Science 2004; 306: 247-252.

14. Sauer H, Rahimi G, Hescheler J, Wartenberg M. Role of reactive oxygen species and phosphatidylinositol 3-kinase in cardiomyocyte differentiation of embryonic stem cells. FEBS Lett 2000; 476: 218 223.

15. Takahashi T, Lord B, Schulze PC, Fryer RM, Sarang SS, Lee RT, et al. Ascorbic acid enhances differentiation of embryonic stem cells into cardiac myocytes. Circulation 2003; 107: 1912-1916.

16. Behfar A, Zingman LV, Hodgson DM, Rauzier JM, Kane GC, Puceat $\mathrm{M}$, et al. Stem cell differentiation requires a paracrine pathway in the heart. FASEB J 2002; 16: 1558-1566.

17. Marvin MJ, Di Rocco G, Gardiner A, Bush SM, Lassar AB. Inhibition of Wnt activity induces heart formation from posterior mesoderm. Genes Dev 2001; 15: 316-327.

18. Schroeder T, Fraser ST, Ogawa M, Nishikawa S, Oka C, Just U, et al. Recombination signal sequence-binding protein Jkappa alters mesodermal cell fate decisions by suppressing cardiomyogenesis. Proc Natl Acad Sci USA 2003; 100: 4018-4023.

19. Winnier G, Blessing M, Labosky PA, Hogan BL. Bone morphogenetic protein-4 is required for mesoderm formation and patterning in the mouse. Genes Dev 1995; 9: 2105-2116.

20. Zhang H, Bradley A. Mice deficient for BMP2 are nonviable and have defects in amnion/chorion and cardiac development. Development 1996; 122: 2977-2986.

21. Sasai Y, Lu B, Steinbeisser H, De Robertis EM. Regulation of neural induction by the Chd and Bmp-4 antagonistic patterning signals in Xenopus. Nature 1995; 376: $333-336$.

22. Lim DA, Tramontin AD, Trevejo JM, Herrera DG, Garcia-Verdugo $\mathrm{JM}$, Alvarez-Buylla A. Noggin antagonizes BMP signaling to create a niche for adult neurogenesis. Neuron 2000; 28: 713-726.

23. Sasai Y, Lu B, Steinbeisser H, De Robertis EM. Regulation of neural induction by the Chd and Bmp-4 antagonistic patterning signals in Xenopus. Nature 1995 ; 376: 333-336.

24. Lim DA, Tramontin AD, Trevejo JM, Herrera DG, Garcia-Verdugo JM, Alvarez-Buylla A. Noggin antagonizes BMP signaling to create a niche for adult neurogenesis. Neuron 2000; 28: 713-726.

25. Yuasa S, Itabashi Y, Koshimizu U, Tanaka T, Sugimura K, Fukuda $\mathrm{K}$, et al. Transient and strong inhibition of BMP signals by Noggin induces cardiomyocyte differentiation in murine embryonic stem cells. Nat Biotech 2005; 23: 607-611.

26. Smith WC, Harland RM. Expression cloning of noggin, a new dorsalizing factor localized to the Spemann organizer in Xenopus embryos. Cell 1992; 70: 829-840.

27. McMahon JA, Takada S, Zimmerman LB, Fan CM, Harland RM, McMahon AP. Noggin-mediated antagonism of BMP signaling is required for growth and patterning of the neural tube and somite. Genes Dev 1998; 12: 1438-1452.

28. Schultheiss TM, Burch JB, Lassar AB. A role for bone morphogenetic proteins in the induction of cardiac myogenesis. Genes Dev 1997; 11: 451-462.

29. Andree B, Duprez D, Vorbusch B, Arnold HH, Brand T. BMP-2 induces ectopic expression of cardiac lineage markers and interferes with somite formation in chicken embryos. Mech Dev 1998; 70: $119-131$

30. Ladd AN, Yatskievych TA, Antin PB. Regulation of avian cardiac myogenesis by activin/TGFbeta and bone morphogenetic proteins. Dev Biol 1998; 204: 407-419.

31. Lyons KM, Hogan BL, Robertson EJ. Colocalization of BMP 7 and BMP 2 RNAs suggests that these factors cooperatively mediate tissue interactions during murine development. Mech Dev 1995; 50: $71-83$.

32. Winnier G, Blessing M, Labosky PA, Hogan BL. Bone morphogenetic protein-4 is required for mesoderm formation and patterning in the mouse. Genes Dev 1995; 9: 2105-2116.

33. Prockop DJ. Marrow stromal cells as stem cells for nonhematopoietic tissues. Science 1997; 276: 71-74.

34. Prockop DJ. Further proof of the plasticity of adult stem cells and their role in tissue repair. J Cell Biol 2003; 160: 807-809.

35. Woodbury D, Schwarz EJ, Prockop DJ, Black IB. Adult rat and human bone marrow stromal cells differentiate into neurons. $J$ Neurosci Res 2000; 61: 364-370.

36. Toma C, Pittenger MF, Cahill KS, Byrne BJ, Kessler PD. Human mesenchymal stem cells differentiate to a cardiomyocyte phenotype in the adult murine heart. Circulation 2002; 105: 93-98.
37. Fukuhara S, Tomita S, Yamashiro S, Morisaki T, Yutani C, Nakatani $\mathrm{T}$, et al. Direct cell-cell interaction of cardiomyocytes is key for bone marrow stromal cells to go into cardiac lineage in vitro. $J$ Thorac Cardiovasc Surg 2003; 125: 1470-1480.

38. Hakuno D, Fukuda K, Makino S, Konishi F, Tomita Y, Manabe T, et al. Bone marrow-derived regenerated cardiomyocytes (CMG Cells) express functional adrenergic and muscarinic receptors. Circulation 2002; 105: 380-386.

39. Tomita Y, Matsumura K, Wakamatsu Y, Matsuzaki Y, Shibuya I, Fukuda K, et al. Cardiac neural crest cells contribute to the dormant multipotent stem cell in the mammalian heart. J Cell Biol 2005; 170: $1135-1146$.

40. Yamauchi Y, Abe K, Mantani A, Hitoshi Y, Suzuki M, Yamamura $\mathrm{K}$, et al. A novel transgenic technique that allows specific marking of the neural crest cell lineage in mice. Dev Biol 1999; 212: 191-203.

41. Li RK, Mickle DA, Weisel RD, Zhang J, Mohabeer MK. In vivo survival and function of transplanted rat cardiomyocytes. Circ Res 1996; 78: $283-288$.

42. Li RK, Mickle DA, Weisel RD, Mohabeer MK, Zhang J, Jia ZQ, et al. Natural history of fetal rat cardiomyocytes transplanted into adult rat myocardial scar tissue. Circulation 1997; 96(Suppl): II-179-II186.

43. Klug MG, Soonpaa MH, Koh GY, Field LJ. Genetically selected cardiomyocytes from differentiating embryonic stem cells form stable intracardiac grafts. J Clin Invest 1996; 98: 216-224.

44. Muller M, Fleischmann BK, Selbert S, Ji GJ, Endl E, Franz WM, et al. Selection of ventricular-like cardiomyocytes from ES cells in vitro. FASEB J 2000; 14: 2540-2548.

45. Moore JC, Spijker R, Martens AC, de Boer T, Rook MB, Mummery $\mathrm{CL}$, et al. A P19Cl6 EGFP reporter line to quantify cardiomyocyte differentiation of stem cells. Int J Dev Biol 2004; 48: 47-55.

46. Kolossov E, Fleischmann BK, Liu Q, Bloch W, ViatchenkoKarpinski S, Hescheler J, et al. Functional characteristics of ES cellderived cardiac precursor cells identified by tissue-specific expression of the green fluorescent protein. J Cell Biol 1998; 143: 2045-2056.

47. Hattan N, Kawaguchi H, Ando K, Kuwabara E, Fujita J, Fukuda K, et al. Purified cardiomyocytes from bone marrow mesenchymal stem cells produce stable intracardiac grafts in mice. Cardiovasc Res 2005; 65: 334-344.

48. Kikuchi A, Okuhara M, Karikusa F, Sakurai Y, Okano T. Two-dimensional manipulation of confluently cultured vascular endothelial cells using temperature-responsive poly(N-isopropylacrylamide)grafted surfaces. J Biomater Sci Polym Ed 1998; 9: 1331 - 1348.

49. Shimizu T, Yamato M, Isoi Y, Akutsu T, Setomaru T, Abe K, et al. Fabrication of pulsatile cardiac tissue grafts using a novel 3-dimensional cell sheet manipulation technique and temperature-responsive cell culture surfaces. Circ Res 2002; 90: 40-48.

50. Itabashi Y, Miyoshi S, Tanimoto K, Yuasa S, Fujita J, Fukuda K, et al. A novel method for manufacturing cardiac cell-sheets using fibrin-polymer-coated dishes and its application for electrophysiological studies by optical mapping. Artif Org 2005; 29: 95-103.

51. Jackson KA, Majka SM, Wang H, Pocius J, Hartley CJ, Goodell MA, et al. Regeneration of ischemic cardiac muscle and vascular endothelium by adult stem cells. J Clin Invest 2001; 107: 1395-1402.

52. Terada N, Hamazaki T, Oka M, Hoki M, Mastalerz DM, Scott EW, et al. Bone marrow cells adopt the phenotype of other cells by spontaneous cell fusion. Nature 2002; 416: $542-545$.

53. Ying QL, Nichols J, Evans EP, Smith AG. Changing potency by spontaneous fusion. Nature 2002; 416: $545-548$.

54. Murry CE, Soonpaa MH, Reinecke H, Nakajima H, Nakajima HO, Field LJ, et al. Haematopoietic stem cells do not transdifferentiate into cardiac myocytes in myocardial infarcts. Nature 2004; 428: $664-668$.

55. Kawada H, Fujita J, Kinjo K, Matsuzaki Y, Tsuma M, Fukuda K, et al. Non-hematopoietic mesenchymal stem cells can be mobilized and differentiate into cardiomyocytes after myocardial infarction. Blood 2004; 104: 3581-3587.

56. Kang HJ, Kim HS, Zhang SY, Park KW, Cho HJ, Park YB, et al. Effects of intracoronary infusion of peripheral blood stem-cells mobilised with granulocyte-colony stimulating factor on left ventricular systolic function and restenosis after coronary stenting in myocardial infarction: The MAGIC cell randomised clinical trial. Lancet 2004; 363: $751-756$.

57. Kovacic JC, Graham RM. Stem-cell therapy for myocardial diseases. Lancet 2004; 363: 1735-1736. 